\title{
Hepatocyte Growth Factor and MET Support Mouse Enteric Nervous System Development, the Peristaltic Response, and Intestinal Epithelial Proliferation in Response to Injury
}

\author{
@Marina Avetisyan, ${ }^{1,2 *}$ Hongtao Wang, ${ }^{1,2 *}$ ๑Ellen Merrick Schill,,${ }^{1,2}$ @Saya Bery, ${ }^{4}$ John R. Grider, ${ }^{5}$ John A. Hassell, ${ }^{6}$ \\ (T)Thaddeus Stappenbeck, ${ }^{2,3}$ and $\odot$ Robert 0 . Heuckeroth ${ }^{1,2,4}$ \\ Departments of ${ }^{1}$ Pediatrics, ${ }^{2}$ Developmental Regenerative and Stem Cell Biology, and ${ }^{3}$ Pathology and Immunology, Washington University School of \\ Medicine, St. Louis, Missouri 63110, ${ }^{4}$ Department of Pediatrics, Perelman School of Medicine at the University of Pennsylvania and The Children's Hospital \\ of Philadelphia Research Institute, Philadelphia, Pennsylvania 19104, 5 Department of Physiology and Biophysics, School of Medicine, Virginia \\ Commonwealth University, Richmond, Virginia 23298, and ${ }^{\circ}$ Department of Biochemistry and Biomedical Sciences, McMaster University, Hamilton, \\ Ontario L8S 4K1, Canada
}

Factors providing trophic support to diverse enteric neuron subtypes remain poorly understood. We tested the hypothesis that hepatocyte growth factor (HGF) and the HGF receptor MET might support some types of enteric neurons. HGF and MET are expressed in fetal and adult enteric nervous system. In vitro, HGF increased enteric neuron differentiation and neurite length, but only if vanishingly small amounts (1 $\mathrm{pg} / \mathrm{ml}$ ) of glial cell line-derived neurotrophic factor were included in culture media. HGF effects were blocked by phosphatidylinositol-3 kinase inhibitor and by MET-blocking antibody. Both of these inhibitors and MEK inhibition reduced neurite length. In adult mice, MET was restricted to a subset of calcitonin gene-related peptide-immunoreactive (IR) myenteric plexus neurons thought to be intrinsic primary afferent neurons (IPANs). Conditional MET kinase domain inactivation $\left(\mathrm{Met}^{f l f f}\right.$; Wnt1Cre+ $)$ caused a dramatic loss of myenteric plexus MET-IR neurites and 1-1' -dioctodecyl-3,3,3',3' -tetramethylindocarbocyamine perchlorate (DiI) labeling suggested reduced MET-IR neurite length. In vitro, Met ${ }^{\text {flffl }}$; Wnt1Cre+ mouse bowel had markedly reduced peristalsis in response to mucosal deformation, but normal response to radial muscle stretch. However, whole-bowel transit, small-bowel transit, and colonic-bead expulsion were normal in $\mathrm{Met}^{f l f l}$; Wnt $1 \mathrm{Cre}+$ mice. Finally, Met ${ }^{f l f l}$; Wnt1Cre+ mice had more bowel injury and reduced epithelial cell proliferation compared with WT animals after dextran sodium sulfate treatment. These results suggest that HGF/MET signaling is important for development and function of a subset IPANs and that these cells regulate intestinal motility and epithelial cell proliferation in response to bowel injury.

Key words: calcitonin gene-related peptide; dextran sodium sulfate (DSS); enteric nervous system; hepatocyte growth factor; intrinsic primary afferent neurons; MET

\section{Significance Statement}

The enteric nervous system has many neuronal subtypes that coordinate and control intestinal activity. Trophic factors that support these neuron types and enhance neurite growth after fetal development are not well understood. We show that a subset of adult calcitonin gene-related peptide (CGRP)-expressing myenteric neurons produce MET, the receptor for hepatocyte growth factor, and that loss of MET activity affects peristalsis in response to mucosal stroking, reduces MET-immunoreactive neurites, and increases susceptibility to dextran sodium sulfate-induced bowel injury. These observations may be relevant for understanding and treating intestinal motility disorders and also suggest that enhancing the activity of MET-expressing CGRP neurons might be a useful strategy to reduce bowel inflammation.

\section{Introduction}

Survival depends on controlled intestinal motility to mix food with digestive enzymes, bring nutrients into contact with gut

Received Dec. 27, 2014; revised June 30, 2015; accepted July 8, 2015.

Author contributions: M.A., H.W., E.M.S., J.R.G., T.S., and R.O.H. designed research; M.A., H.W., E.M.S., S.B., and

J.R.G. performed research; J.A.H. contributed unpublished reagents/analytic tools; M.A., H.W., E.M.S., S.B., J.R.G.,

T.S., and R.O.H. analyzed data; M.A., H.W., J.R.G., T.S., and R.O.H. wrote the paper. epithelium, eliminate waste, and facilitate fluid reabsorption. This requires neuronal networks that sense stretch, villus distortion, and luminal content composition, and then alter motility to suit constantly changing conditions. Fortunately, this occurs 
without conscious thought because the bowel has an intrinsic nervous system called the enteric nervous system (ENS), which controls most aspects of intestinal function (Bornstein et al., 2004; Grundy and Schemann, 2005; Wood, 2008; Furness, 2012; Sasselli et al., 2012; Goldstein et al., 2013). The ENS contains $\geq 20$ neuron subtypes that differ in function, neurotransmitters, axonal projections, and electrophysiology (Furness, 2006b). Some signals governing ENS development and maintenance are known (Sasselli et al., 2012; Lake and Heuckeroth, 2013; Obermayr et al., 2013), but it is unclear how diverse neuronal populations are established or what factors support most enteric neurons after birth. Trophic factors that affect ENS development, maintenance, and function include glial cell line-derived neurotrophic factor (GDNF; Moore et al., 1996; Sánchez et al., 1996; Treanor et al., 1996; Chalazonitis et al., 1998; Hearn et al., 1998; Heuckeroth et al., 1998), neurturin (Heuckeroth et al., 1998, 1999), nerve growth factor (NGF; Mulholland et al., 1994), brain derived neurotrophic factor (Grider et al., 1997b; Boesmans et al., 2008), ciliary neurotrophic factor (Grider et al., 1997a; Chalazonitis et al., 2001; Schäfer et al., 2003), and neurotrophin-3 (Chalazonitis et al., 1994, 1998, 2001). We hypothesized, that hepatocyte growth factor (HGF) and its receptor MET might also be important because HGF supports spinal motor neurons (Ebens et al., 1996), dorsal root ganglion (DRG) subtypes (Maina et al., 1997), retinal ganglion cells (Tönges et al., 2011), and hippocampal neurons (Lim and Walikonis, 2008). Our prior studies also suggested HGF expression in the ENS (Vohra et al., 2006). Finally, we were intrigued by the protective effect of HGF in rodent colitis models (Tahara et al., 2003; Mukoyama et al., 2005; Numata et al., 2005; Oh et al., 2005; Hanawa et al., 2006; Kanbe et al., 2006), and hypothesized that this might be mediated through MET-expressing enteric neurons.

We now demonstrate MET immunoreactivity in most ENS precursors and in a subset of adult calcitonin gene-related peptide (CGRP)-expressing myenteric neurons thought to be intrinsic primary afferent neurons (IPANs; i.e., sensory neurons; Furness et al., 2004a,b). In vitro, HGF/MET signaling influences ENS precursor neurite growth and neuronal differentiation, but conditional Met-null mutations driven by Wnt1Cre [i.e., Met ${ }^{f l / f l}$; Wnt1Cre+ (Met cKO)] did not cause major ENS developmental defects. Met $c K O$ mice had a normal density of MET-immunoreactive (IR) myenteric neurons, but fewer or shorter MET-IR neurites. Met cKO mice also had a specific defect in the peristaltic response elicited by mechanical deformation of intestinal villi. However, in vivo tests of bowel motility were unaltered. Finally, Met $c K O$ mice had increased susceptibility to dextran sodium sulfate (DSS)induced mucosal damage, suggesting that CGRP-expressing enteric neurons protect the bowel from injury and that HGF's ability to protect the bowel might depend on signaling within the ENS.

MD-II-2013-269; R.0.H.); National Institutes of Health Grants R01 DK087715 (R.0.H.), R01 DK34153 (J.R.G.), and R01 DK071619 (T.S.); the Burroughs Wellcome Fund Clinical Scientist Award in Translational Research (Grant 1008525; R.O.H.); and the Canadian Institutes of Health Research (J.A.H.). We thank Dr. Snorri S. Thorgeirsson, Dr. Silvia Arber, and Dr. Kenneth Murphy for generously sharing mice; the Mouse Genetics Core (http://mgc.wustl.edu) for mouse line maintenance; the Washington University Digestive Disease Research Core (P30DK052574) for human tissues; and Karen Carraro, Research Scientific Glass blower in the University of Pennsylvania Glass Shop.

The authors declare no competing financial interests.

*M.A. and H.W. contributed equally to this work.

Correspondence should be addressed to Robert 0 . Heuckeroth, MD, PhD, Professor of Pediatrics, Perelman School of Medicine at the University of Pennsylvania, The Children's Hospital of Philadelphia, Research Institute, Abramson Research Center, 1116i, 3615 Civic Center Blvd, Philadelphia, PA 19104. E-mail: Heuckerothr@email.chop.edu.

DOI:10.1523/JNEUROSCI.5267-14.2015

Copyright $\odot 2015$ the authors $\quad 0270-6474 / 15 / 3511544-16 \$ 15.00 / 0$

\section{Materials and Methods}

Animals. $c-M e t^{f / W T}$ mice (129SV/C57BL/6 background; Huh et al., 2004) were generously provided by Dr. Snorri S. Thorgeirsson (National Cancer Institute, National Institutes of Health, Bethesda, MD). Wnt1Cre mice [STOCK Tg(Wnt1-Cre)11Rth Tg(Wnt1-GAL4)11Rth/J, Stock \#003829, C57BL/6; Swiss albino mixed background] and R26R-EYFP reporter mice (B6.129X1-Gt(ROSA)26Sortm1(EYFP)Cos/J, Stock \#006 148, C57BL/6J) were from The Jackson Laboratory. RET-EGFP mice were previously described (Jain et al., 2006). Etv $5^{M / M}$ and Etv $4^{-1-}$; Etv $5^{\text {lac } Z / W T}$ mice were kindly provided by Dr. Kenneth Murphy (Washington University School of Medicine, St. Louis, MO) and Dr. Silvia Arber (University of Basel, Switzerland). CF-1 mice were from Charles River. The morning of vaginal plug was considered embryonic day (E) 0.5 . Mice of either sex were studied. The use and care of mice were accredited and approved by the Washington University Animal Care Committee and by The Children's Hospital of Philadelphia Research Institute Institutional Animal Care and Use Committee.

Antibodies and reagents. Primary antibodies for mouse analysis were as follows: p75 ${ }^{\mathrm{NTR}}$ antibody (rabbit, 1:1000; \#AB1554, EMD Millipore), Choline acetyltransferases (ChAT; goat, 1:10; \#AB144P, Millipore), calretinin (rabbit, 1:2500; \#AB5054, EMD Millipore), HGF (goat, 1:100; \#sc-1357, Santa Cruz Biotechnology), HuC/D (mouse, 1:200; \#A21272, Invitrogen), GFP (chicken, 1:1000; \#GFP-1020, Aves Labs), S100B (rabbit, 1:800; DAKO), PGP9.5 (guinea pig, 1:100; \#GP14104, Neuromics), TuJ1 (rabbit, 1:10,000; \#PRB-435P, Covance), TuJ1 (mouse; \#MMS-410P, 1:100, Covance), RET (goat, 1:800; \#GT15002, 1:800, Neuromics), RET (R787) (Rabbit, 1:100; \#18121, Immuno-Biological Laboratories), MET (goat, 1:100; AF527, R\&D Systems), CGRP (rabbit, 1:100; \#C8198, Sigma-Aldrich), phosphohistone 3 (pH3; rabbit, 1:800; \#AB06-570, EMD Millipore), neuronal nitric oxide synthase (rabbit, 1:1000; AB\#5380, EMD Millipore), substance P (rabbit, 1:1000; Inestar), vasoactive intestinal polypeptide (VIP; rabbit, 1:1000; Peninsula), NF145 (rabbit, 1:100; \#AB1987, EMD Millipore). Primary antibodies for human gut tissue were as follows: PGP9.5 (rabbit, 1:100; \#7863-0504, Serotec) and c-MET (goat, 1:100; \#AF276, R\&D Systems). Secondary antibodies were as follows: donkey anti-goat Alexa 594 (1:400; Invitrogen), donkey antirabbit Alexa 488 (1:400; Invitrogen), donkey anti-mouse Alexa 647 (1:400; Invitrogen). Tissue culture reagents included GDNF (Creedon et al., 1997), HGF (mouse; \#2207-HG, R\&D Systems), Neurobasal media (Life Technologies), B27 (Life Technologies), DMEM, glutamine (Fisher), penicillin, and streptomycin (Fisher). Inhibitors were as follows: PD98059 (MEK1 inhibitor; \#EI360-0005, Enzo Life Sciences) and LY294002 (PI3K inhibitor; \#ST420-0005, Enzo Life Sciences).

Quantitative ENS analysis. Whole-mount myenteric plexus analysis was performed using $8-12$-week-old mice $(n=3-6)$ as described previously (Wang et al., 2010). Briefly, gut was opened along the mesenteric border, pinned to Sylgard, fixed [4\% paraformaldehyde (PFA), $30 \mathrm{~min}$, $25^{\circ} \mathrm{C}$, and then dissected to separate muscle layers from submucosa. After immunohistochemistry or NADPH diaphorase staining, quantitative analysis was performed. For CGRP antibody staining, peeled gut muscle layers were cultured with colchicine $(0.1 \mathrm{mg} / \mathrm{ml}$; C9754, SigmaAldrich), DMEM, glutamine (2 mM), penicillin (100 IU/ml), and streptomycin $(100 \mu \mathrm{g} / \mathrm{ml})$ for $24 \mathrm{~h}$ before fixation. Neuronal density was quantified by counting cells within 20 randomly selected $20 \times$ fields per mouse. At least three mice of each genotype were analyzed.

Immunohistochemistry and image processing. After fixation, cells, organs, or peeled gut muscle layers were kept in TBST (100 mM Tris, 150 $\mathrm{mm} \mathrm{NaCl}, 0.5 \%$ Triton $\mathrm{X}-100$ ) for $30 \mathrm{~min}$ at $37^{\circ} \mathrm{C}$, blocked with $5 \%$ donkey serum/TBST $\left(30 \mathrm{~min}, 37^{\circ} \mathrm{C}\right)$, and then incubated with primary antibody (overnight, $4^{\circ} \mathrm{C}$ ). Images were obtained with an Olympus BX60 microscope, Axiocam and AxioVision software (Zeiss) or with Zeiss Axio Imager.A2, AxioCam MRm Rev.3 Camera, and ZEN software. Image processing included only cropping and uniform adjustments of brightness, contrast, and saturation.

Human gut. Paraformaldehyde-fixed, paraffin-embedded human colon was obtained from the Washington University Digestive Dis- 
Table 1. Primers for qRT-PCR

\begin{tabular}{lllll}
\hline & & & $5^{\prime}$ to 3'sequences \\
\cline { 3 - 5 } Accession number & Gene symbol & Unigene title & Forward primer & Reverse-strand primer \\
\hline NM_008084 & GAPDH & Glyceraldehyde-3-phosphate dehydrogenase & AAC TTT GGC ATT GTG GAA GG & GTC TTC TGG GTG GCA GTG AT \\
NM_008591 & Met & Met proto-oncogene & CCA GCA GCT TCA GTT ACC GG & GCG ATG CTG ACA TGC CAC TG \\
NM_008815 & Etv4 & Ets variant gene 4 & CCC AGA TGA TGT CTG CAT TG & GCC TGT CCA AGC AAT GAA AT \\
NM_023794.2 & Etv5 & Ets variant gene 5 & GACCCC AGG CTG TAC TTT GA & CAG TCC AGG CGA TGA AGT G \\
\hline
\end{tabular}

ease Research Core Center after approval from the Institutional Review Board at Washington University School of Medicine. Five micrometer sections were deparaffinized and rehydrated for immunohistochemistry.

One-1'-dioctodecyl-3,3,3',3'-tetramethylindocarbocyamine perchlorate labeling combined with immunohistochemistry. Adult mouse bowel was dissected, fixed, and peeled as for quantitative whole-mount analysis. Muscle layers from distal small intestine were cut into 3-cm-long pieces and pinned out on a Sylgard dish. A dissecting pin dipped in NeuroTrace DiI Tissue-Labeling Paste (\#N-22880, Life Technologies) was inserted into the middle of each tissue piece. Pierced samples were kept in 4\% PFA at $37^{\circ} \mathrm{C}$ for 3 weeks. Immunohistochemistry for MET was performed as described above, except that instead of Triton X-100, $1000 \mu \mathrm{g} / \mathrm{ml}$ digitonin (\#D141, Sigma-Aldrich) was used to permeabilize tissue while preserving 1-1'-dioctodecyl-3,3,3',3'-tetramethylindocarbocyamine perchlorate (DiI) staining (Matsubayashi et al., 2008). For cell counting, tissue pieces were evaluated using a $5 \times 7$ grid of $20 \times$ fields centered on the pin insertion site. The grid was additionally subdivided into three zones of varying distances from the pin (see Fig. $5 K$ ) and cells within each $20 \times$ field were counted.

Dissociated cell culture. E12.5 CF-1 ENS precursor cells from dissociated bowel were immunoselected with p75NTR antibody (1:1000) and maintained in culture as previously described (Sato and Heuckeroth, 2008) except that GDNF was not included in media for cell dissociation or immunoselection. Briefly, whole bowel was treated with collagenase $(0.5 \mathrm{mg} / \mathrm{ml})$ and dispase $(0.5 \mathrm{mg} / \mathrm{ml})$, triturated, and filtered through a $40 \mu \mathrm{m}$ cell strainer before incubation with p75 NTR antibody and goat anti-rabbit-coupled paramagnetic beads (Miltenyi Biotec). After separation of p75 ${ }^{\text {NTR }}$-expressing cells using a MACS Separation column (Miltenyi Biotec), immunoselected cells were plated at 6000 cells/well on poly-D-lysine and laminin-coated eightwell chamber slides. Cells were cultured in Neurobasal media supplemented with B27 (2\%), glutamine (2 mM), penicillin (100 IU/ml), and streptomycin $(100 \mu \mathrm{g} / \mathrm{ml})$ for $48 \mathrm{~h}$ before fixation with $4 \%$ PFA and analysis by immunohistochemistry.

Slice culture. E12.5 CF-1 gut slice cultures were performed as described (Fu et al., 2006) with minor modifications. Briefly, 300-500- $\mu$ m-long small-bowel slices were cultured on fibronectin-coated plastic chamber slides (Nunc Lab-Tek, Thermo Scientific) in DMEM, B27 (2\%), glutamine $(2 \mathrm{~mm})$, penicillin $(100 \mathrm{IU} / \mathrm{ml})$, and streptomycin $(100 \mu \mathrm{g} / \mathrm{ml})$. Immediately after plating, slices were treated with PBS (vehicle), HGF, or GDNF at the indicated concentration for $24 \mathrm{~h}$ before fixation (4\% PFA, $15 \mathrm{~min}, 25^{\circ} \mathrm{C}$ ) and processing for immunohistochemistry. For analysis, the distance from the edge of the explant to the most distant TuJ1+ neurites or RET + cells was determined in $\geq 3$ and $\leq 8$ regions per explant.

In vitro peristaltic response. The colon of adult mice was opened along mesenteric attachments to form flat sheets and pinned mucosal side up in a three-chambered organ bath as previously described (Grider and Jin, 1994; Grider et al., 2010). Force-displacement transducers were attached to the circular muscle to record ascending contraction in the orad peripheral compartment and descending relaxation in the caudad compartment. A sensory stimulus that initiates the peristaltic reflex was applied to the bowel in the central chamber. We used a hook-and-pulley system to produce graded $(2-8 \mathrm{~g})$ radial stretch of the circular muscle layer to test the stretch-activated sensory pathway. Mechanical deformation of villi was tested using graded mucosal stroking with a fine brush to stimulate the mucosal-activated pathway.

Whole gastrointestinal transit assay. Adult mice were fed by intragastric gavage with $300 \mu \mathrm{l}$ of $6 \%$ carmine red dye solution (\#C1022, Sigma-
Aldrich) dissolved in distilled water containing 0.5\% methylcellulose (\#274429, Sigma-Aldrich). Mice then were placed into individual cages without bedding. A white sheet of paper covered the cage bottom to facilitate detection of carmine in fecal pellets. Following gavage, cage bottoms were checked for dyed fecal pellets at 10 min intervals. Each mouse was tested three times with $\geq 3 \mathrm{~d}$ between tests.

Colon motility assay. After adult mice were anesthetized with isoflurane, a fire-polished glass rod ( $3 \mathrm{~mm}$ in diameter, custom made by University of Pennsylvania Glass Shop) was used to insert a glass bead ( $3 \mathrm{~mm}$ in diameter; \#Z143928, Sigma-Aldrich) into the rectum, $2 \mathrm{~cm}$ from the anal verge. The glass rod and beads were lubricated with sterile corn oil (\#C8267, Sigma-Aldrich) before insertion. The time required to eject the bead was measured as an estimate of colonic motility. Each mouse was tested three times with $\geq 1 \mathrm{~d}$ between trials.

Small-intestine transit assay. Adult mice were fasted overnight and then fed by intragastric gavage with $100 \mu \mathrm{l}$ of $10 \mathrm{mg} / \mathrm{ml}$ fluorescein isothiocyanate-dextran (FITC-dextran; average molecular weight, 70,000; \#46945 Sigma-Aldrich) dissolved in distilled water containing $2 \%$ methylcellulose. Animals were killed 90 min later and the stomach, small intestine, cecum, and colon were collected in $1 \times$ PBS. Small intestine was divided into 10 segments, cecum into two segments, and colon into three segments. Each segment was opened along the mesenteric border without losing luminal content and placed into an individual $1 \mathrm{ml}$ Eppendorf tube containing $500 \mu \mathrm{l} 1 \times$ PBS. Tubes were vortexed $15 \mathrm{~s}$ and then centrifuged $(2000 \times g, 10$ $\mathrm{min})$ to obtain FITC-dextran-containing supernatant. FITC fluorescence was measured in $100 \mu \mathrm{l}$ aliquots of supernatant in a 96-well plate using a FilterMax F5 (Molecular Devices) plate reader. Smallintestine transit was evaluated by determining the geometric center of the FITC-dextran in the bowel. The geometric center (Miller et al., 1981) was calculated as follows: geometric center $=\sum$ (fluorescence in each segment $\times$ segment number)/total fluorescence recovered.

DSS injury. Colitis was induced with DSS (2.5\% in drinking water) as previously described (Pull et al., 2005). Control littermate mice were placed in separate cages at the time of the experiment and received water without DSS. Anatomic analysis of the colon was done on day 14 after starting DSS or water with the exception of bromodeoxyuridine (BrdU) experiments, which were completed on day 7 . For BrdU studies, mice received intraperitoneal injections $(10 \mathrm{mg} / \mathrm{ml}, 100$ $\mu \mathrm{g} / \mathrm{g}$ body weight) and were analyzed $1 \mathrm{~h}$ later. Colons were pinned flat mucosal side up and fixed $\left(4 \%\right.$ PFA, $\left.30 \mathrm{~min}, 25^{\circ} \mathrm{C}\right)$ before gross morphologic analysis. Longitudinal $5 \mu \mathrm{m}$ sections of paraffinembedded distal and proximal colon were stained with hematoxylin and eosin for additional analysis.

Quantitative reverse transcriptase PCR. Total RNA isolated using TRI Reagent (Sigma-Aldrich) and purified using RNeasy Mini kit (Qiagen) was reverse-transcribed using SuperScript II Reverse Transcriptase (Invitrogen). Quantitative reverse transcriptase PCR (qRT-PCR) was performed in duplicate using SYBR green PCR Master mix (Applied Biosystems) and an iCycler iQ (Bio-Rad). Primers are in Table 1.

\section{Statistical analysis}

SigmaPlot 11 (Systat Software) was used for statistical analyses. All studies included $\geq 3$ biological replicates. Measurements were made by observers blinded to conditions used for studies. Student's $t$ test or one-way ANOVA with post hoc multiple-comparisons tests (Dunn or HolmSidak) were used for statistical analysis. Log-rank testing was performed for analysis of the Kaplan-Meier survival curves. Data are plotted as mean \pm SEM for all graphs. For all tests, $p<0.05$ was considered significant. 

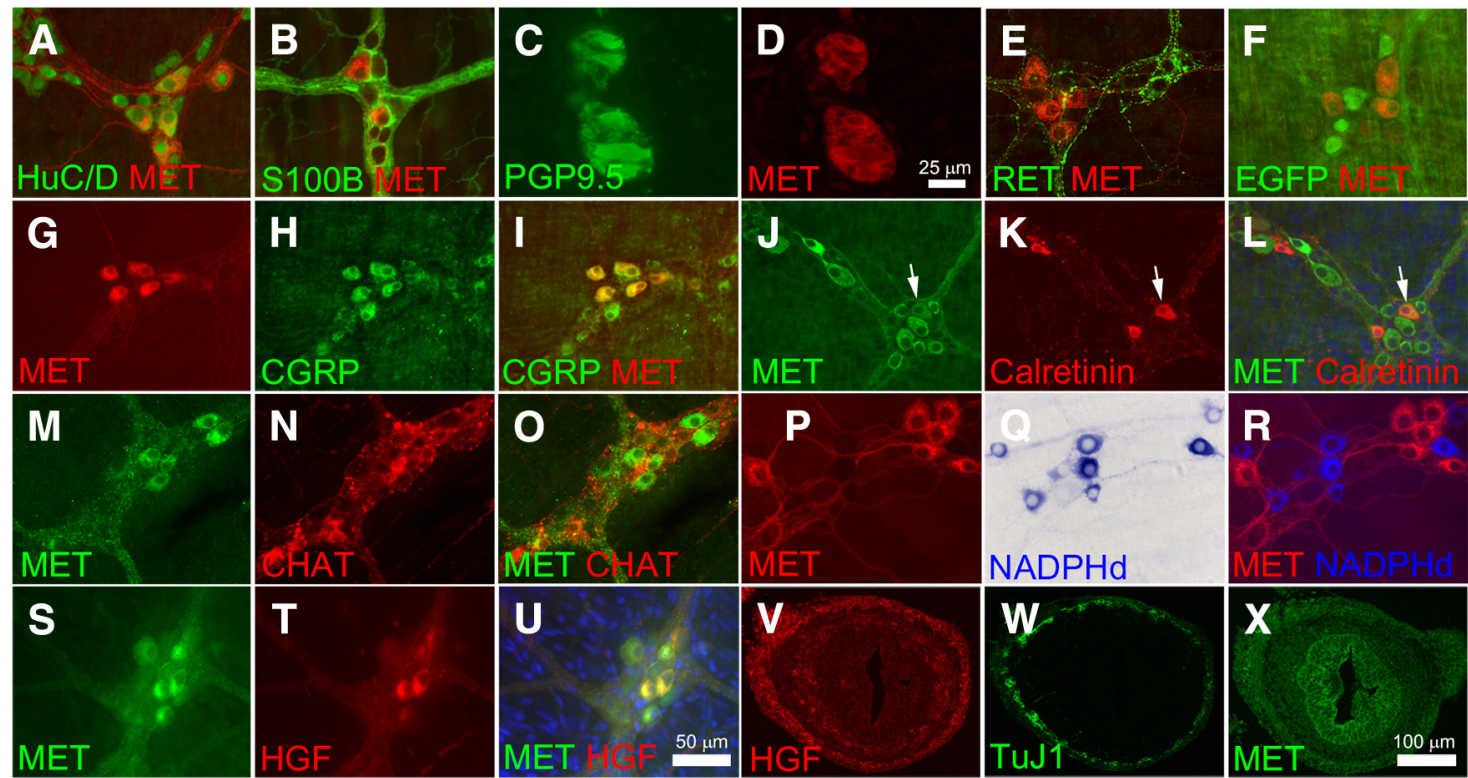

Figure 1. MET immunoreactivity was detected in a subset of myenteric plexus CGRP + IPANs. A, MET immunoreactivity was detected in $34 \pm 6 \%$ of HuC/D + myenteric neurons of the adult mouse small bowel. All MET + cells expressed the pan-neuronal marker HuC/D. B, MET staining was absent from S100B + enteric glia. C, D, MET was detected in human myenteric neurons using colon cross sections. $\boldsymbol{E}, \boldsymbol{F}, \mathrm{MET}$ and RET are detected in mutually exclusive sets of neurons as confirmed by immunohistochemistry $(\boldsymbol{E})$ and by using a RET-EGFP reporter mouse $(\boldsymbol{F})$. G-I, $100 \%$ of MET + neurons were CGRP + and $50 \%$ of CGRP + neurons were MET $+. J-L$, MET was also found in $16 \pm 5 \%$ of calretinin + cells and $8 \pm 2 \%$ of MET + cells are calretinin + . Arrows highlight a MET + calretinin + neuron. $\boldsymbol{M}-\mathbf{0}, 12 \pm 0.1 \%$ of ChAT + cells were MET + and $8 \pm 0.1 \%$ of MET + neurons were ChAT $+. \boldsymbol{P}-\boldsymbol{R}$, There was no overlap between MET and NADPH diaphorase-stained nitric oxide-producing neurons. S-U, HGF was detected in $43 \pm 11 \%$ of MET + neurons and $100 \%$ of the HGF + neurons were MET.$+ \boldsymbol{V}$, In cross sections of E14.5 fetal bowel, HGF-IR was found in mesenchymal cells surrounding developing ENS stained with TuJ $(\boldsymbol{W}) . \boldsymbol{X}$, At E14.5, MET + cells were present in the region of developing ENS as well as in gut epithelium and mesenchymal cells. Scale bars in $\boldsymbol{U}$ applies to $\boldsymbol{A}, \boldsymbol{B}, \boldsymbol{E}-\boldsymbol{U}$. Scale bar in $\boldsymbol{D}$ applies to $\boldsymbol{C}$ and $\boldsymbol{D}$. Scale bar in $\boldsymbol{X}$ applies to $\boldsymbol{V}-\boldsymbol{X}$. $\boldsymbol{N} \geq 3$ replicates/staining condition.

Table 2. Immunohistochemical localization of MET and HGF in the adult mouse small-bowel myenteric plexus

\begin{tabular}{lll}
\hline Method & Percentage of MET + cells that are positive for the "second marker" tested & Percentage of "second marker"-positive cells that are MET + \\
\hline MET + HuC/D & $100 \%$ of MET + are HuC/D + & $34 \pm 6 \%$ of HuC/D + are MET + \\
MET + S100B & $0 \%$ of MET + are S100B + & $0 \%$ of S100B + are MET + \\
MET + CGRP & $100 \%$ of MET + are CGRP + & $49.9 \pm 2 \%$ of CGRP + are MET + \\
MET + RET; MET + RET-EGFP & $0 \%$ of MET + are RET + & $0 \%$ of RET + or EGFP + are MET + \\
MET + HGF & $43 \pm 11 \%$ of MET + are HGF + & $100 \%$ of HGF + are MET + \\
MET + ChAT & $7.6 \pm 0.1 \%$ of MET + are CHAT+ & $12.3 \pm 0.1 \%$ of ChAT + are MET + \\
MET + calretinin & $8.3 \pm 2.3 \%$ of MET + are Calretinin + & $16.4 \pm 5.2 \%$ of calretinin + are MET + \\
MET + NADPHd & $0 \%$ of MET are NADPHd + & $0 \%$ of NADPHd + are MET + \\
\hline
\end{tabular}

\section{Results}

MET and HGF are expressed in a subset of adult enteric neurons Immunohistochemical analysis of adult mouse small bowel demonstrated that MET is present in $34 \pm 6 \%$ of $\mathrm{HuC} / \mathrm{D}+$ myenteric neurons (Fig. 1A) and that all MET + cells express the panneuronal marker $\mathrm{HuC} / \mathrm{D}+$ (Table 2). As expected, MET immunoreactivity was not detected in $\mathrm{S} 100 \mathrm{~B}+$ enteric glia (Fig. $1 B$ ). MET-IR myenteric neurons were also detected in cross sections of human colon, where MET was coexpressed with the neuronal marker PGP9.5 (Fig. 1C,D). To determine which enteric neuron types express MET, remaining studies used adult mouse smallbowel whole-mount preparations to facilitate analysis of many cells at once. Interestingly, RET and MET were detected in mutually exclusive subsets of myenteric neurons as confirmed by immunohistochemistry (Fig. $1 E$ ) and by using a RET-EGFP reporter mouse thought to faithfully reproduce normal Ret expression patterns (Fig. $1 F$ ). One hundred percent of MET + neurons were CGRP-IR and $49.9 \pm 2.0 \%$ of CGRP + neurons were MET+ (Fig. $1 G-I$ ). MET/calretinin staining demonstrated MET immunoreactivity in $16 \pm 5 \%$ of calretinin + cells and that $8 \pm 2 \%$ of $\mathrm{MET}+$ cells are calretinin $+($ Fig. $1 J-L)$. Consistent with this ob- servation, since ChAT is largely expressed in the same cell population, we also detected MET immunoreactivity in $12 \pm 0.1 \%$ of ChAT-IR neurons and found that $8 \pm 0.1 \%$ of MET + neurons were ChAT + (Fig. 1M-O). There was no overlap between MET and NADPH diaphorase-stained nitric oxide-producing neurons (Fig. 1P-R). Thus, MET appears to be primarily expressed in a subset of adult CGRP-expressing cells that are likely to be IPANs. To determine where the MET ligand HGF was expressed in adult mouse bowel muscle layers, HGF/MET double-label immunohistochemistry was performed. Surprisingly, HGF was detected in $43 \pm 11 \%$ of MET + neurons and $100 \%$ of the HGF + neurons had MET immunoreactivity (Fig. $1 S-U$ ). Finally, MET and HGF were also detected in cross sections of E14.5 fetal bowel (Fig. $1 V-X)$. HGF immunoreactivity (Fig. $1 \mathrm{~V}$ ) was prominent in the mesenchymal cells that surround the developing ENS (seen with TuJ1 in Fig. $1 W$ ) and also was detected at lower levels in developing gut submucosa. MET immunoreactivity was present in the region of the developing ENS, but prominent signal was also detected in gut epithelium and in the mesenchymal cells surrounding the ENS, as well as in developing enteric neurons (Fig. $1 X)$. This fetal immunoreactivity for HGF and MET suggested 

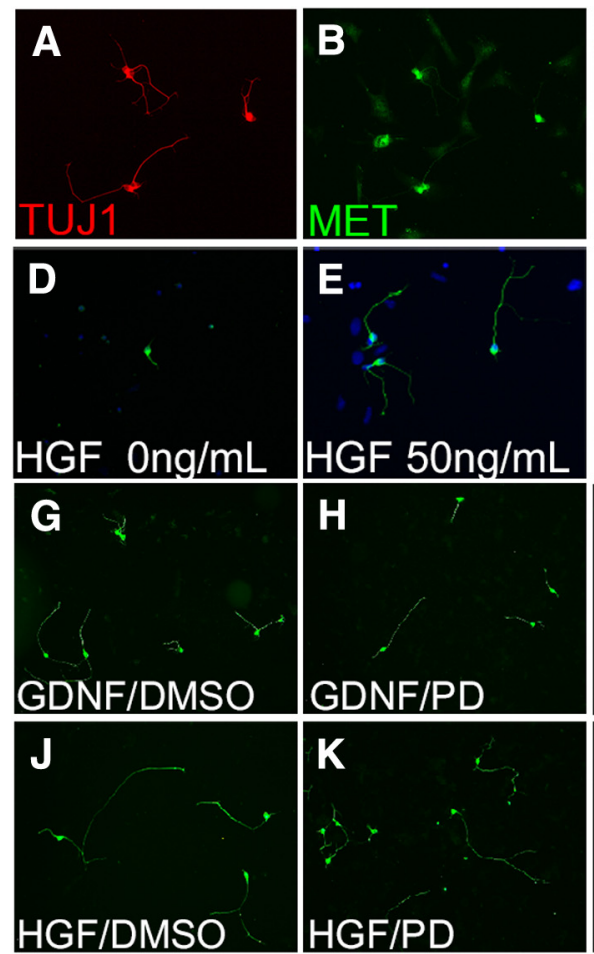

0

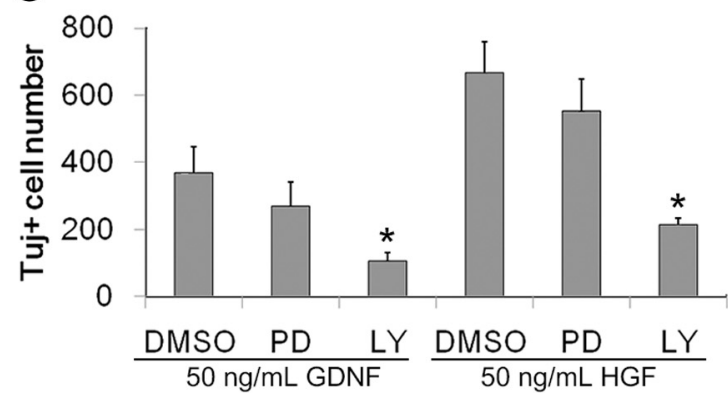

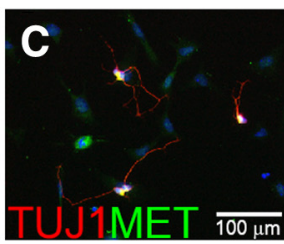
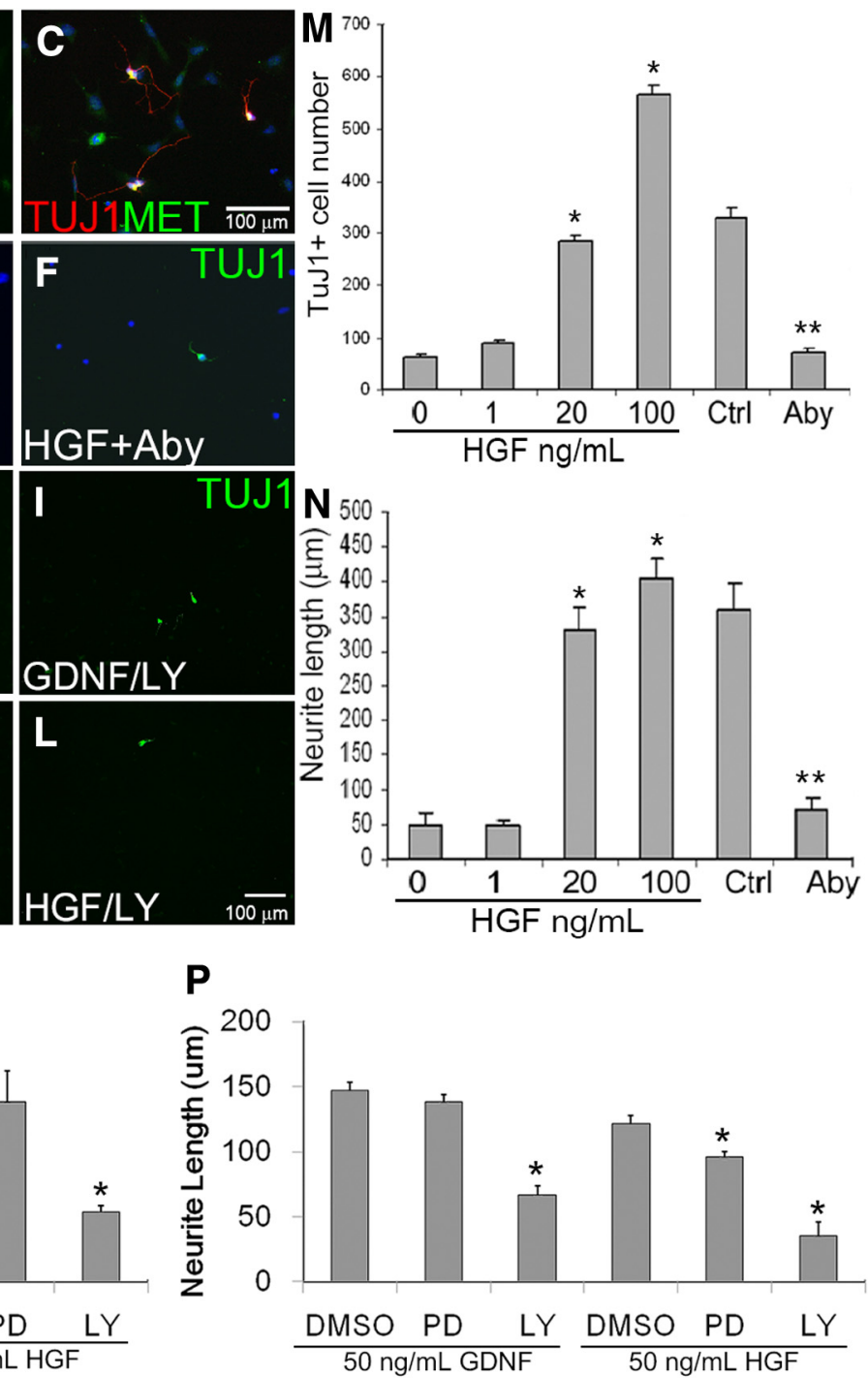

Figure 2. HGF promoted neurogenesis and neurite growth in cultured E12.5 ENS precursor cells. A-C, E12.5 ENS precursors immunoselected with p75 ${ }^{\mathrm{NTR}}$ antibody were maintained in culture for $48 \mathrm{~h}$ in the presence of HGF plus $1 \mathrm{pg} / \mathrm{ml}$ GDNF before TuJ1 and/or MET immunohistochemistry and DAPI nuclear staining. All TuJ1+ enteric neurons were MET-IR. D-F, $\boldsymbol{M}, \boldsymbol{N}, \mathrm{HGF}$ caused a dose-dependent increase in TuJ1-IR neuron number and neurite length. ${ }^{*} p<0.05$, ANOVA with Dunn's multiple-comparison test. $\boldsymbol{F}, \boldsymbol{M}, \boldsymbol{N}, \mathbf{M E T}$ blocking antibody (Aby) reduced TuJ1+ neuron number and neurite length in surviving cells. Control (Ctrl) is $50 \mathrm{ng} / \mathrm{ml} \mathrm{HGF} \mathrm{plus} 1 \mathrm{pg} / \mathrm{ml}$ GDNF. ${ }^{* *} p<0.01$, Student's $t$ test. $\mathbf{G}-\boldsymbol{L}, \mathbf{0}, \boldsymbol{P}$, When ENS precursors were grown in GDNF alone, the MEK inhibitor PD98059 (PD) had no effect on neuron number or neurite length, but the PI-3K inhibitor LY294002 (LY) reduced neuron number and neurite length. In contrast, in HGF (50 ng/ml) plus GDNF $(1 \mathrm{pg} / \mathrm{ml})$-treated cells, both MEK and PI-3K inhibition reduced neurite length $(\boldsymbol{P})$, whereas only PI-3K inhibition reduced neuron number (0). ${ }^{*} p<0.01$, ANOVA with Dunn's multiple-comparison test. Scale bar in $\mathbf{C}$ applies to $\boldsymbol{A}-\boldsymbol{F}$. Scale bar in $\boldsymbol{L}$ applies to $\mathbf{G}-\boldsymbol{L}$. ( $N \geq 3$ biological replicates/group; 12 individual wells/group).

that these proteins might have roles during development as well as in the adult ENS.

HGF and MET signaling support fetal ENS neurogenesis and neurite growth in vitro

To determine whether HGF/MET signaling could affect fetal ENS development, we cultured ENS precursors from E12.5 bowel after immunoselection with $\mathrm{p} 75^{\mathrm{NTR}}$ antibody. In these dissociated cell cultures, we initially tried adding HGF at a range of concentrations $(0-100 \mathrm{ng} / \mathrm{ml})$ to Neurobasal media, with B-27 supplement and L-glutamine, but in the absence of added GDNF, ENS precursors grew poorly or died and there was no evidence that HGF had any effect. When we tried including GDNF at commonly used concentrations (e.g., 50 or $100 \mathrm{ng} / \mathrm{ml}$ ) in the media, the trophic effects of GDNF were so strong that no additional effect of HGF could be discerned. Recognizing that the concentrations of GDNF used commonly in culture are higher than the
ED50 for GDNF-induced ENS precursor proliferation (1.5 ng/ ml; Heuckeroth et al., 1998) and dramatically higher than the dissociation constant value (Kd) for GDNF binding to GFR $\alpha 1$ (30 pg/ml; Jing et al., 1996), we decided to titrate the GDNF to low levels that might be more physiologic, yet support ENS precursor survival and permit effects of HGF to be observed. Under these conditions, all $\mathrm{TuJ} 1+$ enteric neurons were also MET antibody-IR (Fig. 2A-C). Remarkably, including GDNF at 1 $\mathrm{pg} / \mathrm{ml}(50,000-100,000$-fold less than is typically used in culture) led to robust and dose-dependent effects of HGF (Fig. 2D,E). ENS precursors were therefore immunoselected with $\mathrm{p} 75^{\mathrm{NTR}}$ and cultured at low density with $1 \mathrm{pg} / \mathrm{ml}$ GDNF plus either $0,1,20,50$, or $100 \mathrm{ng} / \mathrm{ml} \mathrm{HGF}$. In cultures containing only low levels of GDNF, there were very few TuJ1+ cells in culture after $48 \mathrm{~h}$. Increasing HGF doses led to progressively more TuJ1+ cells in culture, with a sixfold increase in TuJ1 + cells in cultures contain- 
ing $100 \mathrm{ng} / \mathrm{ml}$ HGF plus $1 \mathrm{pg} / \mathrm{ml}$ GDNF compared with cells maintained in GDNF alone (Fig. 2M). Including HGF in culture media also dramatically increased average neurite length compared with $1 \mathrm{pg} / \mathrm{ml}$ GDNF alone (Fig. $2 N$ ). We confirmed that the HGF effects are MET dependent using MET-blocking antibody and $50 \mathrm{ng} / \mathrm{ml} \mathrm{HGF}$ (Fig. $2 E, F, M, N$ ). Under these conditions, the blocking antibody almost completely prevented HGF effects on $\mathrm{TuJ} 1+$ cell number and neurite length.

Given the similarity of HGF and GDNF effects on the number of TuJ1 + cells in culture and on neurite length, we hypothesized that GDNF and HGF depend on the same signaling pathways to support neurogenesis and neurite growth. We previously reported, using rat enteric neurons, that GDNF-induced increases in neuron number and neurite length depend on phosphatidylinositol 3-kinase (PI3K), but not MEK signaling (Srinivasan et al., 2005). Using the MEK inhibitor PD98059 and the PI3K inhibitor LY294002, we confirmed these findings in mice using p $75^{\mathrm{NTR}}$-immunoselected E12.5 ENS precursors in culture (Fig. $2 G-I, O, P)$. Similar to the results obtained using GDNF alone at $50 \mathrm{ng} / \mathrm{ml}$, the number of TuJ $1+$ cells present after $48 \mathrm{~h}$ in culture with HGF $(50 \mathrm{ng} / \mathrm{ml})$ plus GDNF $(1 \mathrm{pg} / \mathrm{ml})$ was reduced by the PI3K inhibitor, but not by the MEK inhibitor. In contrast, neurite length was reduced by both PI3K and MEK inhibitors in HGFcontaining cultures (Fig. $2 J-L$ ), but only by the PI3K inhibitor in the GDNF (50 ng/ml) cultures (Fig. 2P). This difference in downstream effectors suggests that HGF/MET-induced neurite growth and GDNF/RET-induced neurite growth support ENS precursors via partially overlapping signaling pathways.

\section{HGF/MET signaling enhances ENS precursor differentiation into} neurons in vitro

The increase in TuJ1+ cells in dissociated ENS precursor cultures in response to HGF plus $1 \mathrm{pg} / \mathrm{ml}$ of GDNF could occur because of increased precursor proliferation, reduced cell death, or enhanced differentiation of RET $+/ \mathrm{TuJ} 1-$ precursors into RET+/TuJ1+ cells. To distinguish between these possibilities, dissociated $\mathrm{p} 75^{\mathrm{NTR}}$-immunoselected cells from E12.5 mouse bowel were cultured in media with GDNF (1 $\mathrm{pg} / \mathrm{ml}$ ) with and without HGF (50 $\mathrm{ng} / \mathrm{ml}$ ) for $48 \mathrm{~h}$ and then stained with TuJ1, RET, and pH3 antibodies (Fig. $3 A-H$ ). RET is expressed in ENS precursors and differentiated neurons and $\mathrm{TuJ} 1$ immunoreactivity is a marker of neuronal differentiation, whereas $\mathrm{pH} 3$ identifies mitotic cells. While the total number of RET + cells was not significantly altered with HGF (Fig. $3 I$ ), the number of TuJ1+ cells and the proportion of RET + cells that are TuJ1-IR was increased by HGF (Fig. $3 J, K)$. HGF also decreased the number of RET + TuJ1 - cells in culture, and reduced the number of dividing $(\mathrm{pH} 3+$ / RET+) ENS precursors (Fig. 3L). Collectively these data suggest that HGF increased the number of TuJ $1+$ enteric neurons in vitro by enhancing ENS precursor differentiation into neurons instead of through increased precursor proliferation or survival.

\section{HGF/MET signaling did not increase ENS precursor migration} in vitro

Since HGF and MET are expressed in fetal bowel when ENS precursors migrate and have well known effects on migration of other neuronal cell types (Giacobini et al., 2007; Garzotto et al., 2008), we hypothesized that HGF/MET signaling might influence ENS precursor migration. To test this hypothesis, E12.5 gut slices were cultured on fibronectin-coated culture dishes and ENS precursors were allowed to migrate from the slice onto the culture dish for $24 \mathrm{~h}$. Addition of GDNF ( $100 \mathrm{ng} / \mathrm{ml})$ to the media mark- edly increased the distance that ENS precursors migrated onto the culture dish (Fig. 4). In contrast, HGF (50 or $100 \mathrm{ng} / \mathrm{ml}$ ) did not increase enteric neural crest-derived cell (ENCDC) migration onto the culture dish compared with no added factor, suggesting that HGF may not be needed for ENCDC migration in vivo.

MET inactivation within ENS precursors causes selective defects in MET-expressing enteric neurons

$\mathrm{Met}^{-1-}$ mice die in utero between E13.5 and E16.5 (Huh et al., 2004). Therefore, to investigate the role of HGF/MET signaling in the ENS in vivo, we bred mice with LoxP sites surrounding Met exon 16 to Wnt 1 Cre transgenic animals to generate $\mathrm{Met} c \mathrm{KO}$ mice $\left(\mathrm{Met}^{f l / f l} ;\right.$ Wnt $\left.1 \mathrm{Cre}+\right)$. CRE-dependent recombination inactivates MET by removing the intracellular kinase domain, but should permit production of a truncated protein that includes the extracellular and transmembrane domain. The Wnt1Cre transgene is expressed in the developing neural tube and neural crest derivatives, including the ENS, but not in other cells within the bowel. Thus Met cKO mice should have selective loss of MET activity in ENS precursors within the bowel without affecting other intestinal cell lineages. Met $\mathrm{CKO}$ mice survive to adulthood and are born at rates that are not statistically different from expected Mendelian ratios $\left(p>0.99, \chi^{2}\right.$ test $)$.

To test the hypothesis that Met mutations might slow migration of ENS precursors down the fetal bowel, we evaluated ENS structure in Met cKO and control littermates (Met WT or CRE deficient) using TuJ1 and RET antibodies. Consistent with in vitro migration studies, control and Met cKO mice had ENCDCs in the entire small bowel and half the colon at E12.5 and there were no obvious differences in ENS structure (data not shown). We then examined the adult mouse myenteric plexus to test the hypothesis that HGF/MET signaling influences the development of MET-expressing CGRP + enteric neurons. Using an antibody to the MET extracellular domain to stain the myenteric plexus, we found that MET + neuronal cell bodies are easy to identify in $\mathrm{Met}$ cKO mice and that these cells were normal in size (Fig. 5A) and abundance (Fig. 5B). In contrast, MET-IR interganglionic and intraganglionic neurites are very difficult to see in Met cKO mice compared with control animals (Fig. 5C,D). To determine whether this staining pattern reflects a difference in neurite length for myenteric plexus MET-expressing neurons, we performed DiI labeling combined with MET immunohistochemistry. DiI paste on a dissecting pin was inserted into fixed smallbowel muscle layers containing the myenteric plexus and tissue was incubated for 3 weeks. DiI taken up by axons undergoes passive retrograde diffusion through lipid membranes to label cell bodies away from the pin site (Fig. $5 E-J$ ). Costaining of DiIlabeled samples with MET antibody revealed that the number of DiI and MET-double-positive cell bodies was dramatically reduced in Met cKO mice compared with controls, especially as the distance from the DiI-labeling site increased (Fig. $5 K-N$ ). In contrast, the average number of MET-positive cell bodies was not different at varying distances away from the pin site (Fig. $5 \mathrm{M}, O$ ). Furthermore, the number of MET-negative neuron cell bodies labeled by DiI did not significantly differ in WT and Met cKO mice (data not shown). These data suggest that neurites in MET-IR myenteric neurons of Met cKO mice are shorter than in WT mice.

\section{Functional analysis of gut motility}

To test the hypothesis that HGF/MET signaling is important for intestinal motility, the peristaltic response to stretch or to mechanical stimulation of the mucosal lining was measured in WT 

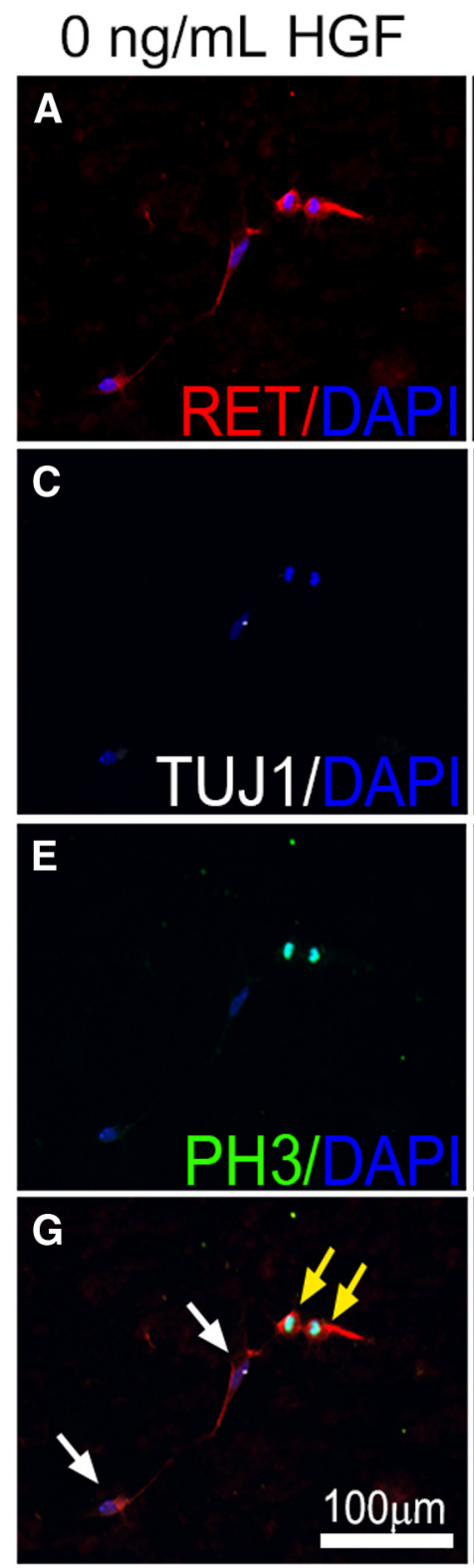

$50 \mathrm{ng} / \mathrm{mL} \mathrm{HGF}$
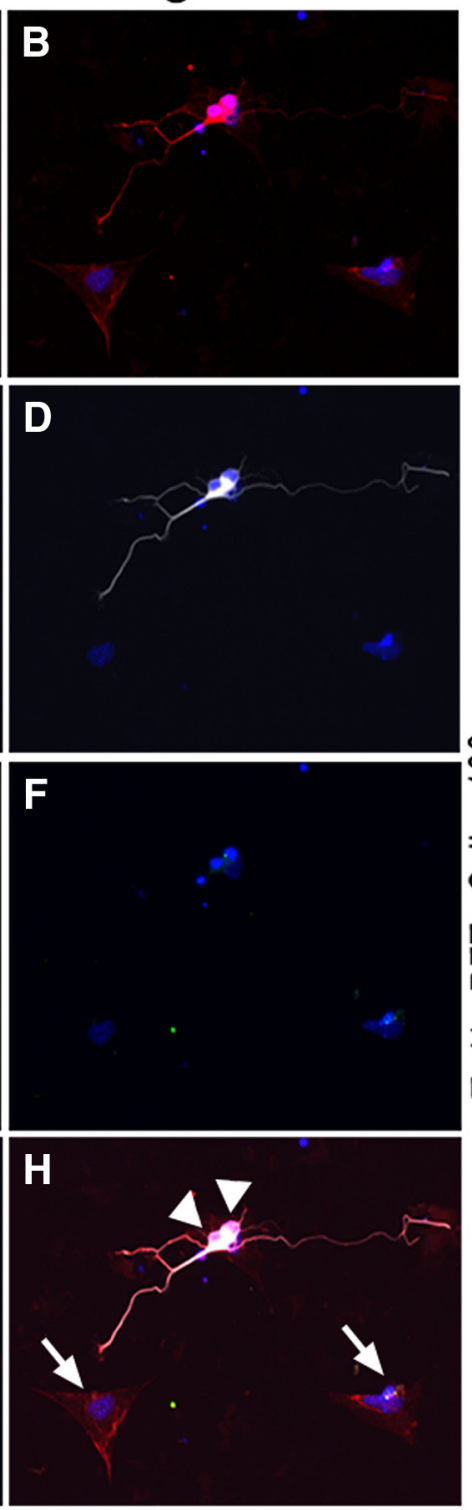
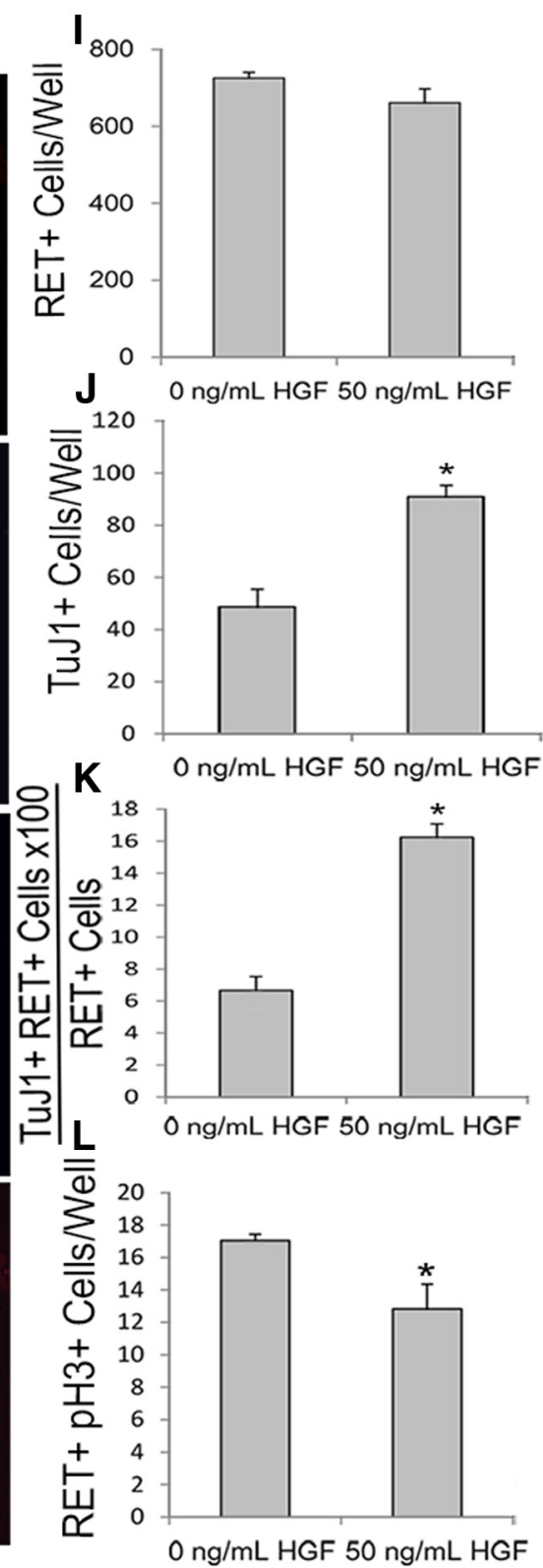

Figure 3. HGF/MET signaling enhanced ENS precursor differentiation into neurons in vitro. $\boldsymbol{A}-\boldsymbol{H}, \mathrm{E} 12.5 \mathrm{ENS}$ precursors were maintained in culture after $\mathrm{p} 75^{\mathrm{NTR}}$ immunoselection for $2 \mathrm{~d}$ in the presence or absence of $50 \mathrm{ng} / \mathrm{ml}$ HGF before immunohistochemistry using RET $(\boldsymbol{A}, \boldsymbol{B})$, TuJ $1(\boldsymbol{C}, \boldsymbol{D})$, and pH3 $(\boldsymbol{E}, \boldsymbol{F})$ antibodies as well as DAPI nuclear staining $(\boldsymbol{A}-\boldsymbol{H})$. $\mathbf{G}, \boldsymbol{H}$, Merged images. $\boldsymbol{I}-\boldsymbol{K}$, While the total number of RET + cells was not altered by HGF $(\boldsymbol{I})$, the total number of TuJ1+ neurons $(\boldsymbol{J})$ and the percentage of RET + cells that were TuJ1+ $(\boldsymbol{K})$ increased with HGF treatment. $L$, The number of dividing precursor cells ( $\mathrm{pH} 3$ and RET double positive) decreased with HGF treatment, suggesting that HGF increased neuronal differentiation and decreased proliferation. White arrows, Nonmitotic RET + pH3 - ENS precursors. Yellow arrow, Mitotic RET + PH3 + ENS precursors. White arrowhead, RET + TuJ1+ neurons. Scale bar in $\mathbf{G}$ applies to all images ( $N=3$ biological replicates/group; 12 individual wells/group; ${ }^{*} p<0.01$, Student's $t$ test).

and Met cKO mice using an oxygenated three-compartment organ bath. These studies showed that the ascending and descending components of the peristaltic reflex were strongly blunted in Met $t^{f / f l}$; Wht1Cre + mice in response to gentle brushing of the mucosa (Fig. 6A, $B, E$ ). In contrast, both components were similar in $W T$ and Met cKO mice when the peristaltic reflex was elicited by muscle stretch (Fig. 6C,D). These data suggest that Met mutations cause a selective defect in one of the sensory signaling modalities capable of initiating peristalsis (i.e., the reflex elicited by mucosal stimulation). Despite this defined defect in the peristaltic reflex, whole gastrointestinal transit as measured using carmine dye (Fig. $6 F$ ), gastric emptying and small-intestine transit measured by FITC-dextran gavage (Fig. $6 G$ ), and colonic motility measured by expulsion of a glass bead from the rectum (Fig. $6 \mathrm{H}$ ) were not altered in Met cKO mice compared with controls. These data suggest that intact sensory response to villus deformation is not required for normal transit of luminal contents through the bowel.

HGF/MET signaling and bowel injury

HGF/MET signaling potently reduces bowel injury in response to the toxins DSS and 2,4,6-trinitrobenzene sulfonic acid in rodent models and supports epithelial cell proliferation (Tahara et al., 2003; Mukoyama et al., 2005; Numata et al., 2005; Oh et al., 2005; Hanawa et al., 2006; Kanbe et al., 2006; Setoyama et al., 2011). We hypothesized that these effects might be mediated by the newly 


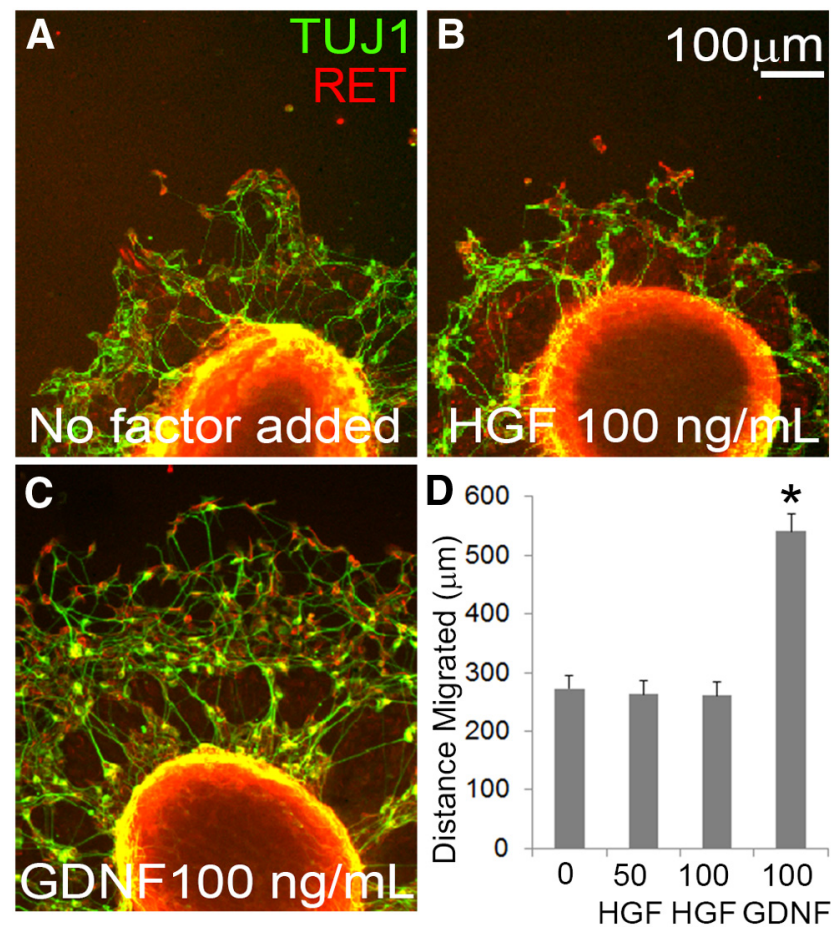

Figure 4. HGF/MET signaling did not increase ENS precursor migration in culture. $A-C, E 12.5$ gut slices were cultured $24 \mathrm{~h}$ on fibronectin-coated dishes with no added factor, HGF, or GDNF before staining for RET and TuJ1.A, ENCDCs migrate from the gut slice onto the culture dish even without any added factors. $\boldsymbol{B}$, HGF did not increase the distance that ENCDCs migrated from the edge of the gut slice. C, GDNF markedly increased the distance ENCDCs migrate from the edge of the gut slice. D, Quantitative data (no added factor, 15 slices; $50 \mathrm{ng} / \mathrm{ml} \mathrm{HGF,} 14$ slices; $100 \mathrm{ng} / \mathrm{ml}$ HGF, 19 slices; $100 \mathrm{ng} / \mathrm{ml}$ GDNF, 30 slices; $N=3$ independent experiments). ${ }^{*} p<0.001$ for GDNF versus no added factor, ANOVA with Dunn's multiple-comparison test.

discovered MET-expressing neurons. To test this hypothesis, we treated $\mathrm{Met}^{f l f f}$; Wnt1Cre+ mice or control littermate animals with $2.5 \%$ DSS in drinking water and analyzed the colon after 2 weeks of DSS treatment. Met flffl Wnt1Cre+ mice had significantly more mucosal damage than control animals after $14 \mathrm{~d}$ of DSS treatment (Fig. $7 A-F$ ) and higher death rates (Fig. $7 G$ ). Because increased damage in specific models, including DSS, is linked to diminished epithelial proliferation, we examined intestinal stem and progenitor cell proliferation and found that Met cKO mice had reduced proliferation compared with control animals after $7 \mathrm{~d}$ of DSS (Fig. $7 \mathrm{H}-\mathrm{J}$ ). Collectively these data suggest that HGF/MET signaling protects the intestinal mucosa from DSS-induced injury through the activity of MET-expressing enteric neurons since the only cells in the bowel that express CRE in this model are in the ENS.

GDNF/RET signaling increased Met and Etv5 mRNA in cultured ENS precursors, but MET protein levels in vivo do not depend on Etv5/Etv4

The requirement for very small amounts of GDNF to detect any HGF effects on neurite growth and neuron numbers is striking, especially since MET and RET are closely related tyrosine kinase receptors. One possible explanation is that GDNF/RET signaling is needed to induce Met expression in cultured ENS precursors as occurs in the kidney and motor neurons via the Etv4 (Pea3) and Etv5 (Erm) transcription factors (Haase et al., 2002; Livet et al., 2002; Lu et al., 2009; Kuure et al., 2010). To test this hypothesis, we cultured E12.5 immunoselected ENS precursors for $18 \mathrm{~h}$ with or without $1 \mathrm{pg} / \mathrm{ml}$ GDNF. Although extended culture without GDNF results in death of ENS precursors, there were many healthy-appearing ENS precursors in the GDNF-deprived cultures and in cultures containing $1 \mathrm{pg} / \mathrm{ml}$ of GDNF when the mRNA was collected after $18 \mathrm{~h}$ in culture. Relative mRNA levels for Etv4,Etv5, and Met were analyzed by real-time qRT-PCR. We found that compared with cells cultured without GDNF, ENS precursors grown with $1 \mathrm{pg} / \mathrm{ml}$ GDNF had an eightfold increase in Etv5 mRNA, a 230-fold increase in Met mRNA, but no change in Etv 4 mRNA. These data suggest that low levels of GDNF induced Met expression, allowing HGF to affect ENS precursor development (Fig. 8A,B).

To further explore the role of ETV5 signaling in MET expression in vivo, we examined MET expression in the ENS of $E t v 5^{M / M}$ animals, as well as in Etv $4^{-/-}$; Etv $5^{\text {lac } Z / W T}$ compound mutants (Lu et al., 2009). Etv $5^{M / M}$ allele is a weak allele that permits survival to adulthood. In contrast, the Etv $5^{\text {lac } Z}$ allele used in the $E t v 4^{-/-} ; E t v 5^{l a c Z / W T}$ mice causes early fetal lethality, prohibiting analysis of the Etv $5^{\text {lacz/lac }}$ ENS. We found that the ENS of $E t v 5^{M / M}$ and $E t v 4^{-/-} ; E t v 5^{\text {lac } Z / W T}$ compound mutants was grossly normal, with MET-IR neuron density comparable to that of WT littermates (Fig. 8C-H). In contrast, in the developing kidney, where GDNF also induces Met expression, the Etv4 ${ }^{-1-}$; $E t v 5^{\text {lac } Z / W T}$ compound mutants fail to express Met in the ureteric bud, causing serious defects in renal development ( $\mathrm{Lu}$ et al., 2009). This suggests that ETV4 and ETV5 are dispensable for MET expression in enteric neurons or that at single allele of Etv5 is adequate for MET expression in the ENS.

\section{Discussion}

HGF enhanced fetal enteric neuron differentiation and neurite growth in vitro, but did not affect ENS precursor migration from gut slices or bowel colonization by ENS precursors in vivo. In adults, MET immunoreactivity was found in a subset CGRP+ myenteric neurons thought to be IPANs (Qu et al., 2008). MET-IR neuron density was normal in Met cKO mice, but MET-IR neurites were short and sparse. Met cKO mice also had reduced peristalsis after mucosal deformation and increased mucosal injury after DSS exposure. These data suggest HGF and MET support a subset of CGRP-expressing IPANs that regulate intestinal motility and epithelial function.

\section{HGF, MET, GDNF, and RET}

MET influences many cellular functions (Trusolino et al., 2010), including neuron survival (spinal motor, sympathetic, sensory, and retinal neurons; Ebens et al., 1996; Maina et al., 1997; Thompson et al., 2004; Lamballe et al., 2011; Tönges et al., 2011), differentiation (sensory and hippocampal neurons; Maina et al., 1997; Lim and Walikonis, 2008), axon outgrowth and guidance (spinal motor, gonadotropin-releasing hormone (GNRH), sensory, and retinal neurons; Ebens et al., 1996; Maina et al., 1997; Giacobini et al., 2007; Tönges et al., 2011), precursor migration (cortical and GNRH neurons; Giacobini et al., 2007; Garzotto et al., 2008), and synaptic plasticity (hippocampal neurons; Akimoto et al., 2004). Our data reveal previously unsuspected roles for MET and HGF in the ENS, but there is more to learn. One intriguing question is whether HGF in some MET-IR neurons acts as a chemoattractant to support formation of the extensive network of IPAN-to-IPAN connections (Furness et al., 2004a). HGF is chemoattractive for spinal motor axons (Ebens et al., 1996), but has autocrine roles in sympathetic neurons (Maina et al., 1998) and may have similar ENS functions. Another interesting finding was that HGF effects required small amounts of GDNF, which increased Met and Etv5 mRNA (Lu et al., 2009; Costantini, 2010). In kidney, Met was absent in $E t v 4^{-/-} ; E t v 5^{\text {lac Z/WT }}$ mice, but MET was readily detected in myenteric neurons, suggest- 
A
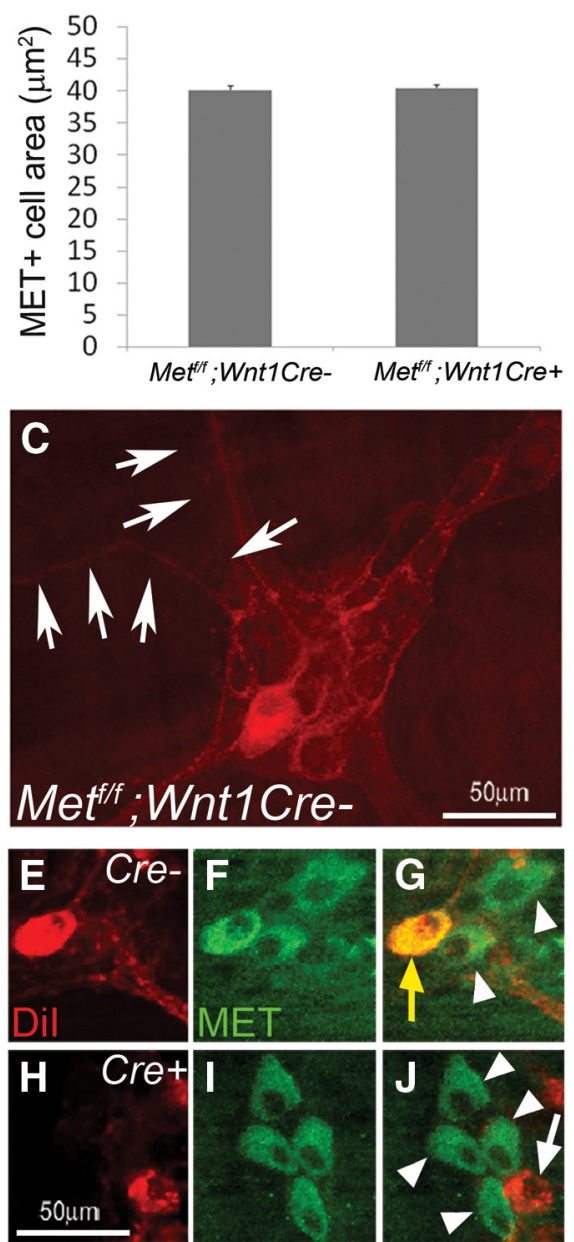

L Cre-
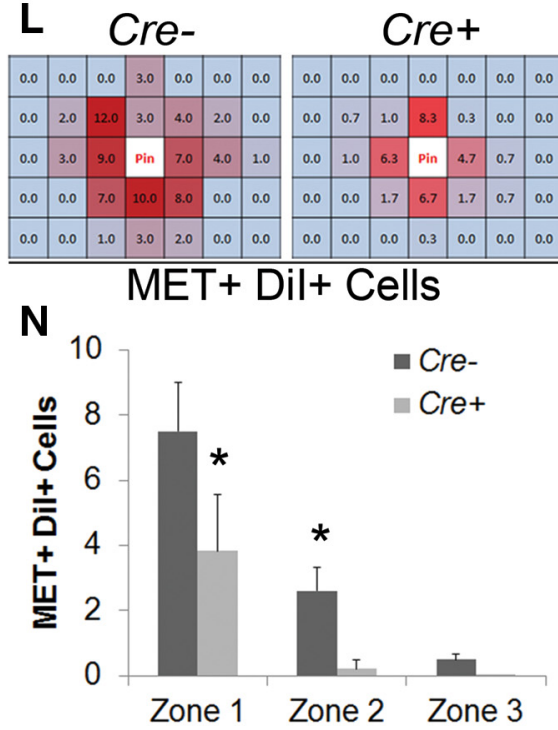

B
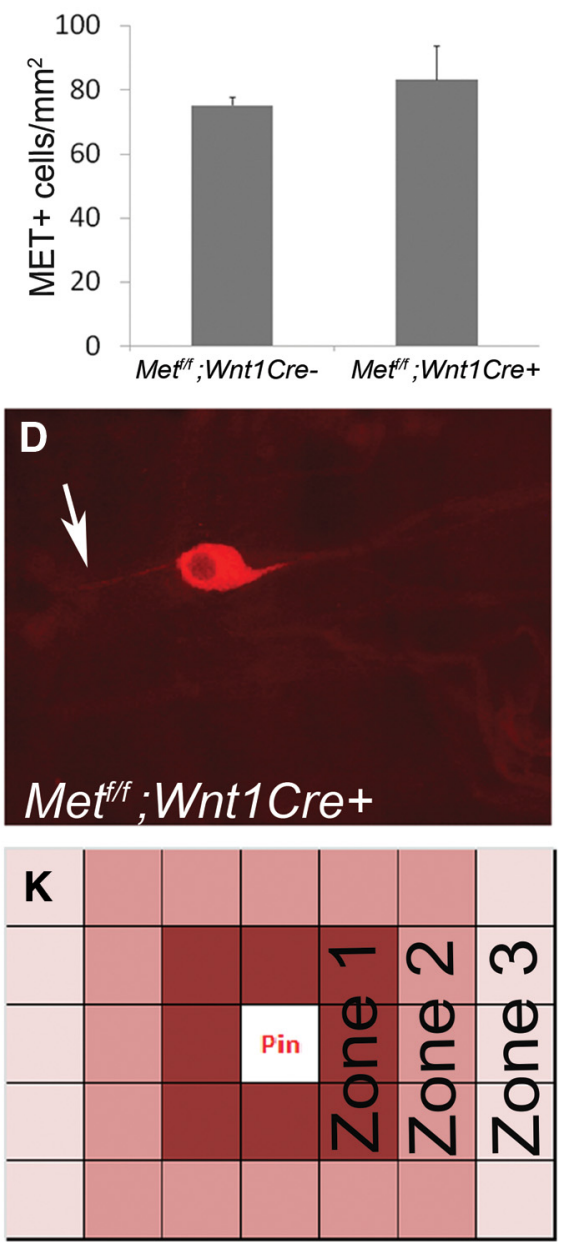

M Cre-

Cre+

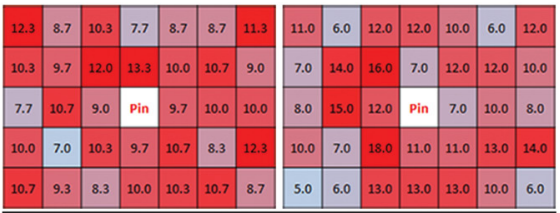

o

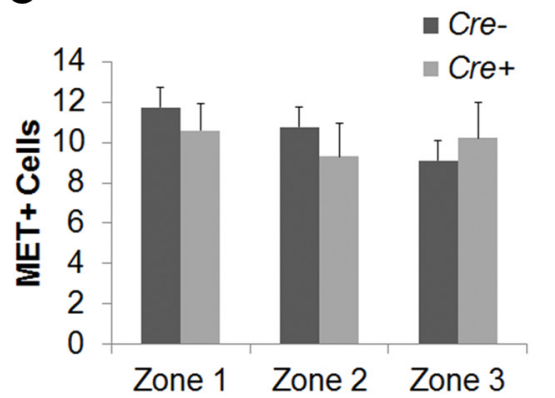

Figure 5. MET deletion within ENS precursors caused selective defects in MET-expressing enteric neurons in adult mice. $\boldsymbol{A}, \boldsymbol{B}$, The myenteric plexus of mice lacking functional MET receptors in the ENS $\left(\mathrm{Met}^{t f / f} ;\right.$ Wnt $\left.1 \mathrm{Cre}+\right)$ contained MET + neuronal cell bodies of normal size and abundance ( $N=3$ mice of each genotype/condition). C, $D, M e t^{t f / f} ; W n t 1 C r e+$ mice had few interganglionic and intraganglionic MET-IR neurites ( $N=6$ mice of each genotype/condition). $\boldsymbol{E}-\boldsymbol{J}$, Double-labeling for myenteric neurons combining Dil labeling and MET immunohistochemistry. Cells shown were two $20 \times$ fields away from the Dil application site. Yellow arrow, Dil + MET + cell body. White arrow, Dil + MET - cell body. White arrowheads, Dil - MET + cell bodies $(N=4$ mice of each genotype; $N>8$ distal small-bowel Dil-labeled regions/genotype). $\boldsymbol{K}$, Schematic for analysis of Dil/MET-labeled samples: tissue pieces were divided into a $5 \times 7$ grid of $20 \times$ fields centered on the pin insertion site. The grid was additionally

ing single Etv5 alleles may support ENS Met expression. Unfortunately, Etv $5^{\text {lacZ/lac Z }}$ mice die early (Lu et al., 2009) and milder Etv $5^{M / M}$ mutations did not affect MET-IR myenteric neuron density, so ETV5 function in the ENS remains uncertain. Finally, MET and RET appear in nonoverlapping adult myenteric neuron populations, highlighting the need to define mechanisms restricting receptor tyrosine kinases (e.g. RET, NTRK3, and MET) to specific enteric neuron subtypes (Chalazonitis et al., 1994, 2001; Schuchardt et al., 1994; Heuckeroth et al., 1999; Uesaka et al., 2007, 2008).

\section{HGF/MET and ENS development}

The requirement for $1 \mathrm{pg} / \mathrm{ml}$ GDNF to observe HGF effects on ENS precursors is reminiscent of synergistic HGF and NGF effects in DRG. HGF alone did not support DRG neuron survival or axon outgrowth, but HGF enhanced survival, differentiation, and axonogenesis with NGF present (Maina et al., 1997, 1998). In the ENS, low GDNF levels maintain cells as progenitors (Uesaka et al., 2013) and may support survival while enhancing HGF responsiveness. In contrast, high GDNF triggers neuronal differentiation and migration, masking HGF effects. GDNF concentrations in vivo are unknown but are probably below the $50-100 \mathrm{ng} / \mathrm{ml}$ commonly used in vitro, since increased and reduced GDNF alters enteric neuron number (Gianino et al., 2003; Wang et al., 2010) and the Kd for GDNF binding to GFR $\alpha 1$ is only $30 \mathrm{pg} / \mathrm{ml}$ (Jing et al., 1996). These observations suggest that it may be appropriate to evaluate how other factors affect ENS precursors in the presence of low concentrations of GDNF instead of the levels typically used in culture.

\section{HGF/MET and IPAN subtypes}

Functional data suggest IPANs are heterogeneous (Clerc and Furness, 2004; Furness et al., 2004a; Furness, 2006a). For example, stretch opens IPAN gadolinium-insensitive mechanosensitive ion channels (Kunze et al., 1999), whereas mucosal deformation triggers serotonin and ATP release from enteroendocrine cells to activate IPAN $5 \mathrm{HT}_{3} / 5 \mathrm{HT}_{4}$ or P2X receptors (Grider and Jin, 1994; Pan and

\section{$\leftarrow$}

subdivided into three zones of varying distances from the pin. $\boldsymbol{L}, \boldsymbol{M}$, Heat map representations of the average number of MET + Dil + cells $(\boldsymbol{L})$ and total MET + cells $(\boldsymbol{M})$ in each $20 \times$ field of the grid. Dark red $>$ light red $>$ blue for the number of cells in each region. $\boldsymbol{N}$, The number of Dil + MET + cell bodies was dramatically reduced in $\mathrm{Met}$ CKO mice compared with controls in Zones 1 and 2. ${ }^{*} p<0.02$ (Student's $t$ test). $\boldsymbol{0}$, The number of total MET + cell bodies did not differ at varying distances from the pin site. 


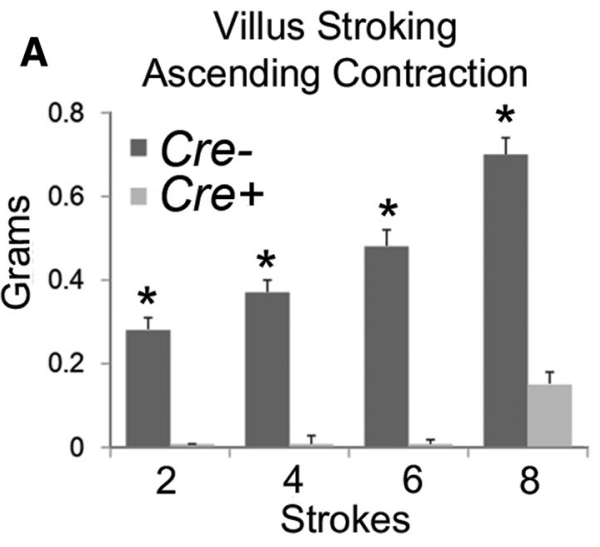

C

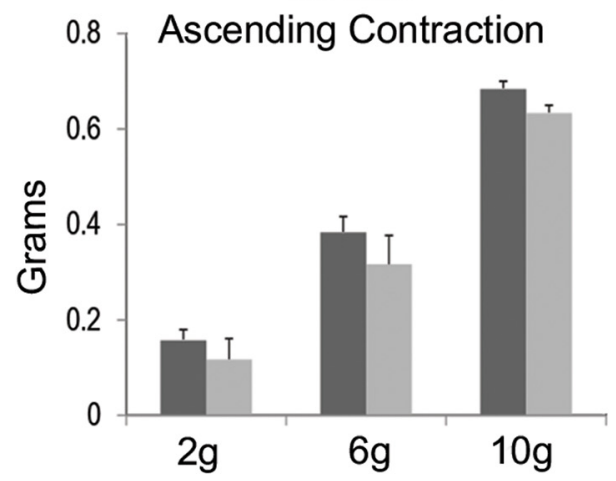

E

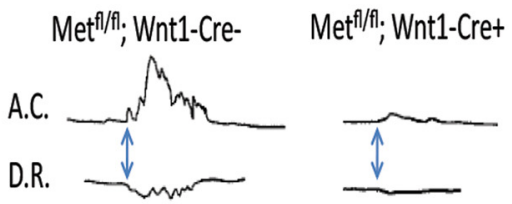

G

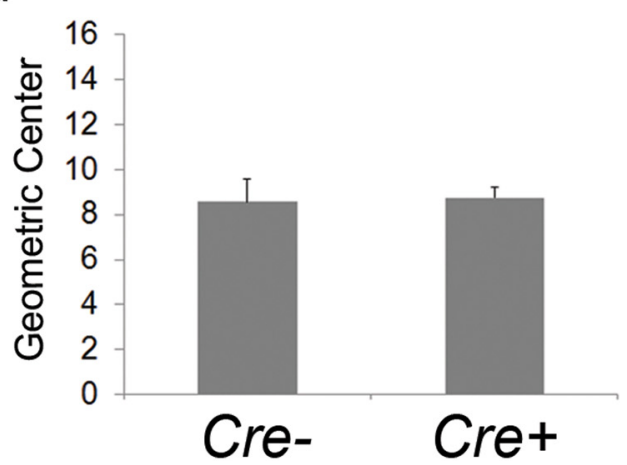

B

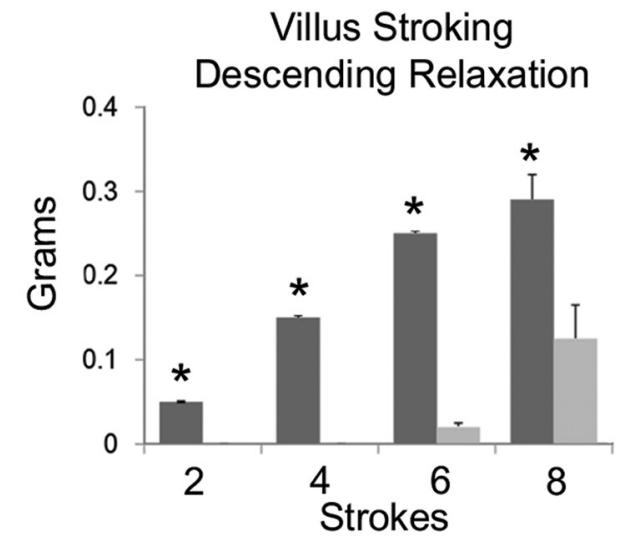

D

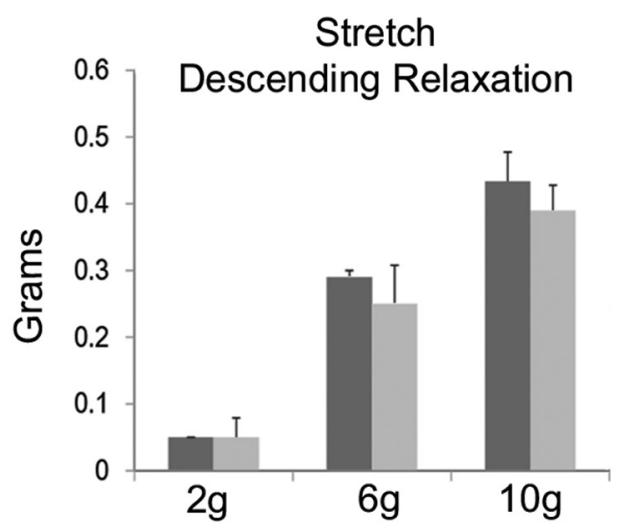

F

H
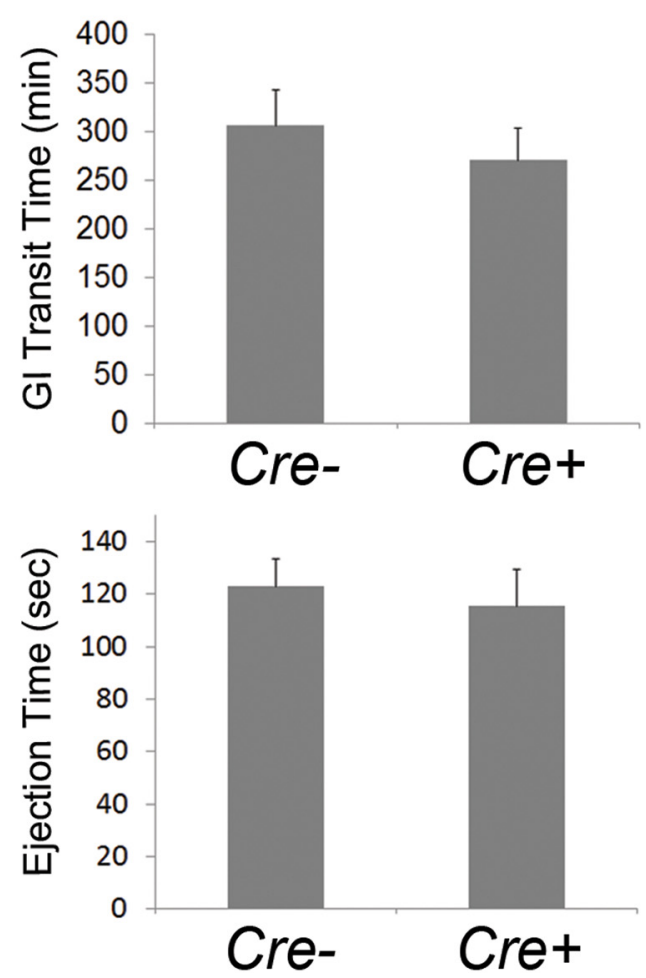

Figure 6. MET deletion within ENS precursors resulted in selective defects in the sensory arm of the peristaltic response. $\boldsymbol{A}, \boldsymbol{B}, \boldsymbol{E}$, Mice lacking functional MET receptors in the ENS $\left(\right.$ Met ${ }^{f / f l}$; Wnt1 $(\mathbf{C}+)$ had an abnormal peristaltic reflex in response to mechanical stimulation of the villi, as evidenced by a severely blunted ascending contraction $(\boldsymbol{A})$ and descending relaxation $(\boldsymbol{B})$. $\boldsymbol{C}, \boldsymbol{D}$, In contrast, the peristaltic reflex elicited by circular muscle stretch had normal ascending contraction $(\boldsymbol{C})$ and descending relaxation $(\boldsymbol{D})$ in Met ${ }^{f / f f} ;$;nt 1 Cre + mice, suggesting a selective sensory defect $\left(N=3\right.$ mice/genotype; ${ }^{*} p<0.01$, Student's $t$ test). $\boldsymbol{F}$, Whole gastrointestinal transit as measured by the time needed to pass orally gavage-fed carmine dye in stool was not altered in $M e t^{f l f l}$; Wnt 1 Cre + mice ( $N=8$ Met cKO and 7 control mice). G, Small-bowel transit as measured by determining the geometric center of FITC-dextran within the bowel 90 min following oral gavage was not altered in $\mathrm{Met}^{\mathrm{fl} / \mathrm{fl}}$;Wnt1 $\mathrm{Cre}+$ mice ( $\mathrm{N}=4 \mathrm{Met} \mathrm{CKO}$ and 4 control mice). $\boldsymbol{H}$, Colonic transit, as measured by the time taken to expel a bead placed $2 \mathrm{~cm}$ into the distal colon was not altered in $\mathrm{Met}^{\mathrm{fl} / \mathrm{fl}} ; \mathrm{Wnt1}$ Cre + mice $(\mathrm{N}=8 \mathrm{Met} \mathrm{CKO}$ and 7 control mice). 


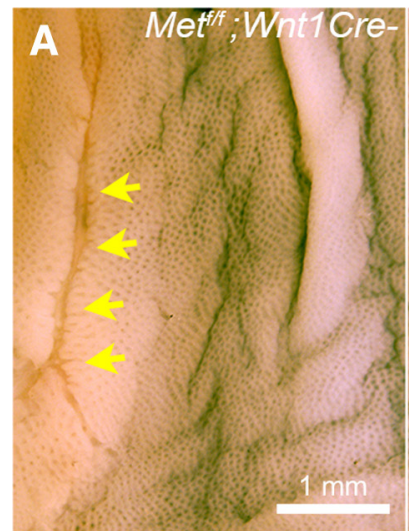

E
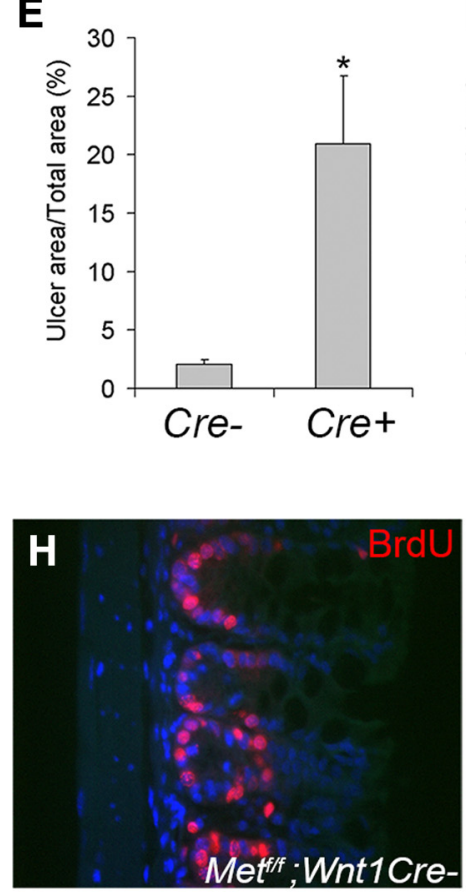

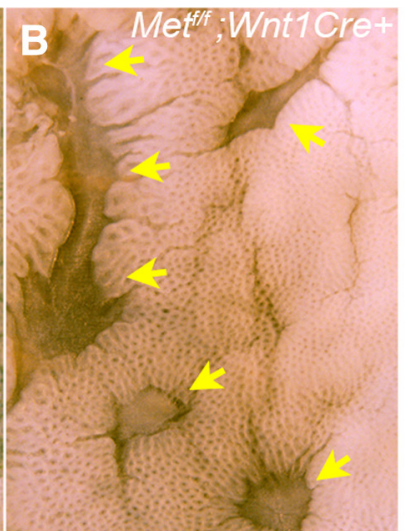

F
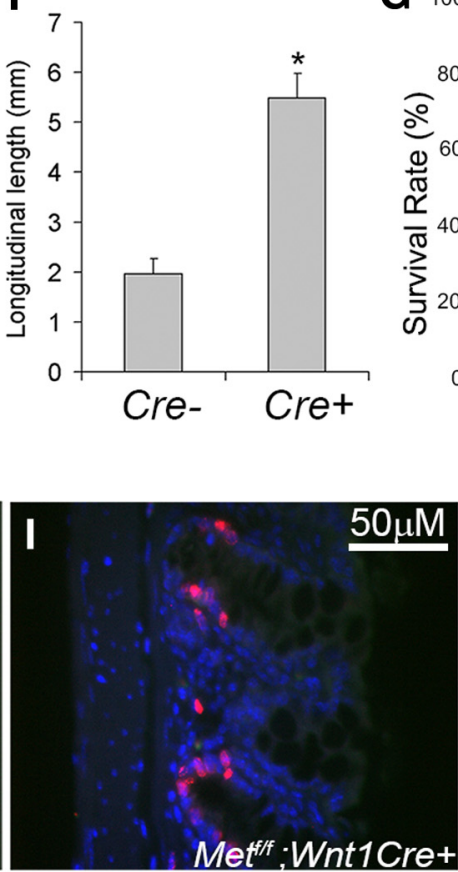
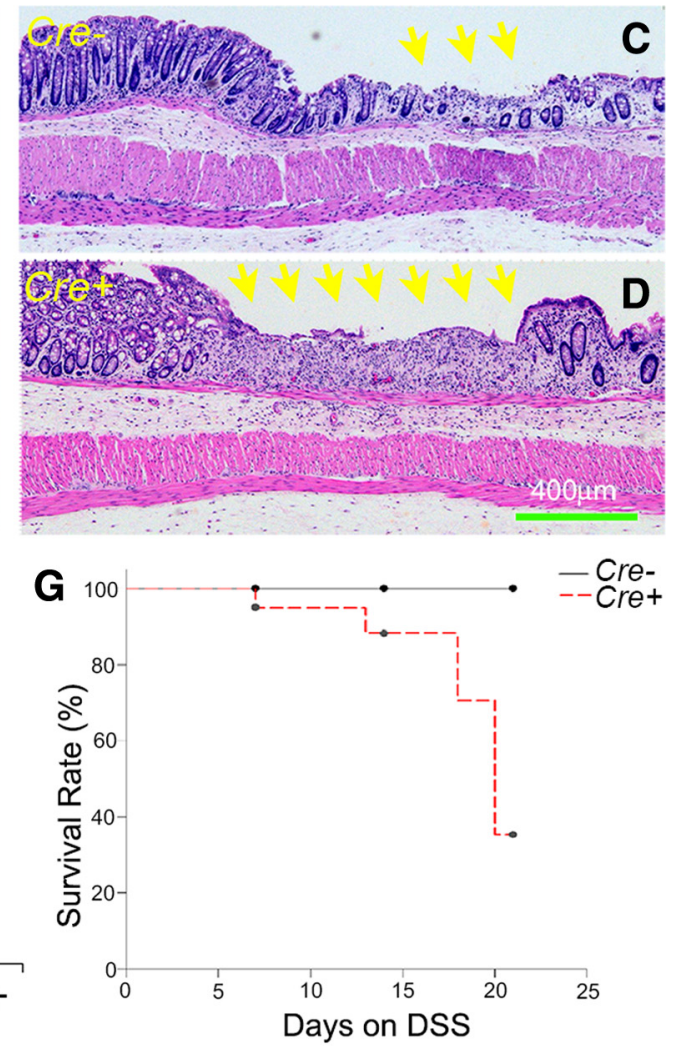

-Cre-
--Cre+

\section{.}

. 
A
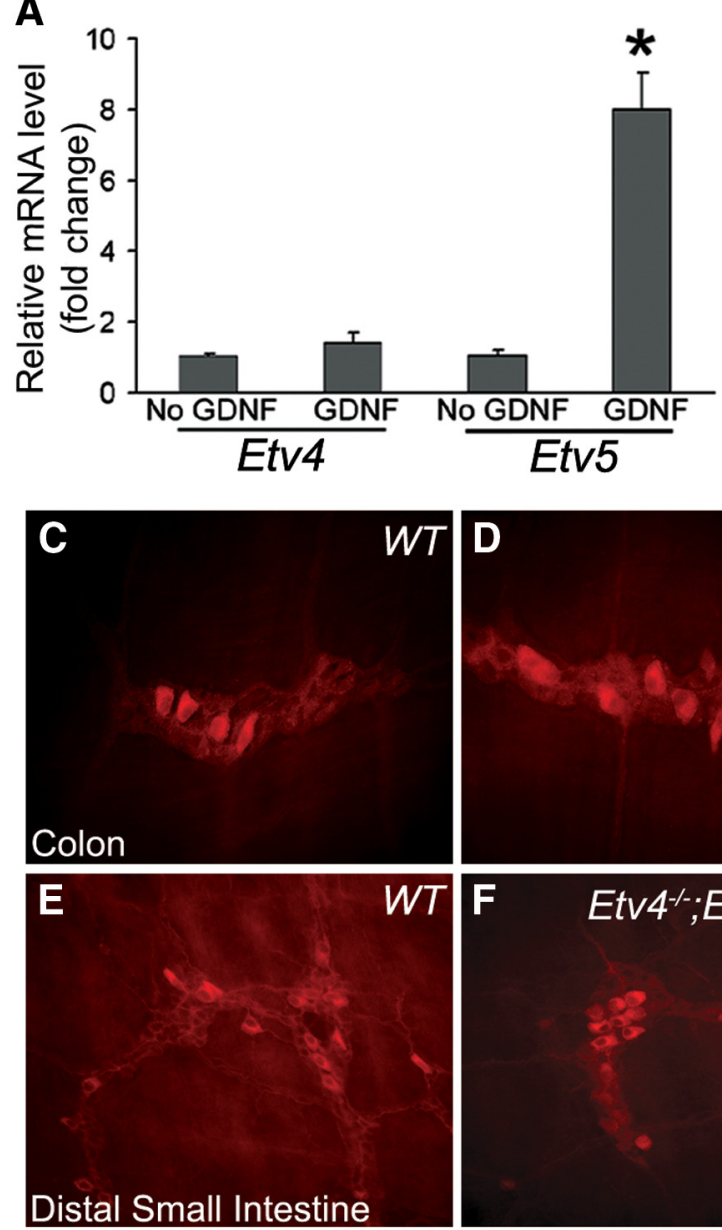

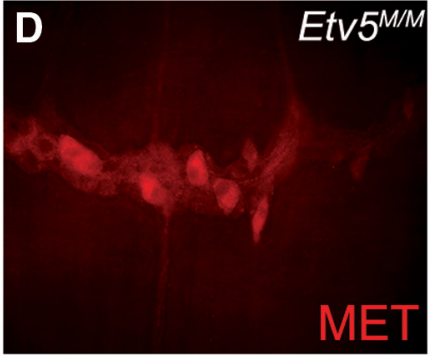

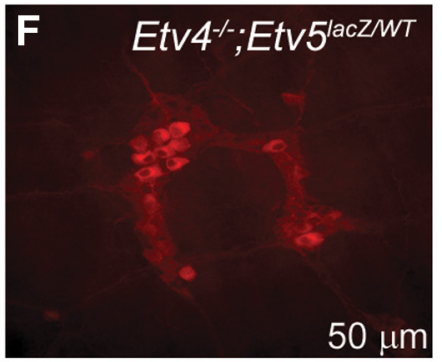

B

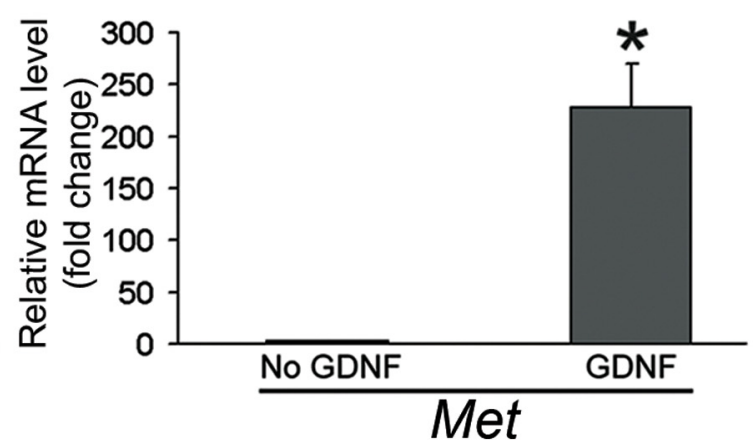

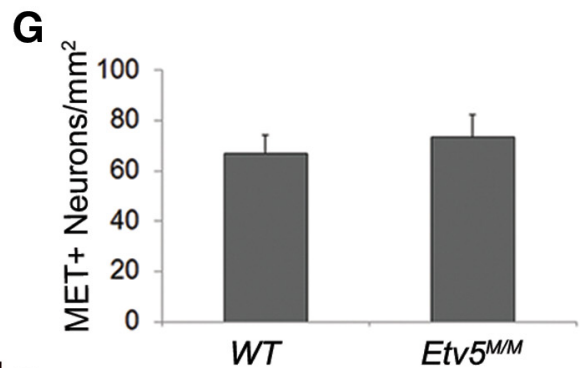
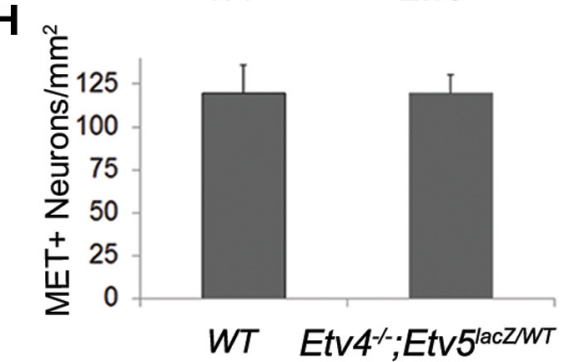

Figure 8. GDNF/RET signaling increased Met and Etv5 mRNA in cultured ENS precursors, but MET protein immunoreactivity appeared normal in mice with Etv4 and Etv5 mutations. $A$, ENS precursors grown with $1 \mathrm{pg} / \mathrm{ml}$ GDNF had an eightfold increase in Etv5 mRNA, but not in Etv $4 \mathrm{mRNA}$ when compared with precursors cultured without GDNF. $\boldsymbol{B}$, ENS precursors grown with $1 \mathrm{pg} / \mathrm{ml}$ GDNF also had a 230-fold increase in Met mRNA ( $N=3$ biological replicates). $\mathbf{C}-\boldsymbol{H}$, The myenteric plexus of adult Etv5 ${ }^{M / M}$ mice and P14 Etv $4^{-\prime-} ;$ Etv5 ${ }^{\text {lacZ } / W T}$ compound mutants appeared grossly normal with no differences in MET-IR neuron density ( $N=3$ mice for each group). ${ }^{*} p<0.01$ (Student's $t$ test).

Many mechanisms might underlie our observations. One hypothesis is that impaired injury response results from reduced CGRP release from MET+ enteric neurons. CGRP mutations increased colonic damage in DSS-treated mice (Thompson et al., 2008). Furthermore, CGRP is a potent vasodilator (Pawlik et al., 2000) and adequate mucosal blood flow may facilitate injured bowel repair. CGRP also supports bowel epithelial proliferation via mast cells and fibroblasts producing transforming growth factor $\alpha$ (Hoffmann et al., 2010) and by regulating gene expression in macrophages (Baliu-Piqué et al., 2014) that influence the set point of intestinal epithelial proliferation (Baliu-Piqué et al., 2014; Sun et al., 2015). MET+ neurons might also support epithelial proliferation via acetylcholine release from ChAT +MET + neurons, since acetylcholine enhances epithelial growth (Tutton, 1975; Lundgren et al., 2011; Gross et al., 2012).

Consistent with ENS support for bowel epithelium, enteric neurons express the receptor for glucagon-like peptide 2, a potent epithelial mitogen (Bjerknes and Cheng, 2001; Guan et al., 2006), and neuronal serotonin increases epithelial proliferation (Gross et al., 2012). However, myenteric plexus ablation increases epithelial cell proliferation (Zucoloto et al., 1988; Holle, 1991; Hadzijahic et al., 1993; Holle et al., 2003) and hypomorphic Ret $^{+--}$mice (Gianino et al., 2003) had in- creased epithelial proliferation after small-bowel resection (Hitch et al., 2012). These data suggest distinct enteric neuron subtypes enhance or inhibit intestinal epithelial proliferation, but it is unclear how these processes are integrated.

We also note that CRE-induced MET mutations are not restricted to the ENS in Met cKO mice (Danielian et al., 1998). MET should be disrupted in CGRP-expressing DRG neurons (Gascon et al., 2010) that might normally enhance mucosal repair (Takami et al., 2009; Engel et al., 2011, 2012; Lee et al., 2012). MET inactivation in vagal neurons (Freem et al., 2010) could also increase severity of DSS-induced injury (Mazelin et al., 1999; Ghia et al., 2006, 2007; Van Der Zanden et al., 2009) since some vagal nuclei express Met (Caton et al., 2000; Wu and Levitt, 2013). Distinguishing between these possibilities is not straightforward, but these data fit with an emerging literature suggesting neuronal activity regulates intestinal epithelial progenitor proliferation and barrier function (Bjerknes and Cheng, 2001; Nezami and Srinivasan, 2010; Hitch et al., 2012; Sharkey and Savidge, 2014).

It is tempting to speculate that neurogenic control underlies high rates of enterocolitis in children with Hirschsprung disease, a birth defect where the ENS is absent from distal bowel (Frykman and Short, 2012; Heuckeroth, 2013). ENS damage in inflammatory bowel disease or necrotizing entero- 
colitis may also perpetuate bowel inflammation (Margolis and Gershon, 2009; Zhou et al., 2013). Indeed, many ENS transmitters affect bowel inflammation and injury, including CGRP (Eysselein et al., 1992; Wang et al., 2006; Ramachandran et al., 2013), serotonin (Bischoff et al., 2009; Gershon, 2012), neuropeptide Y, VIP (Chandrasekharan et al., 2013), and substance P (Landau et al., 2007), as do enteric glia (Bush et al., 1998; Savidge et al., 2007), enteric neuron density (Margolis et al., 2011), and toll-like receptor 2 (Brun et al., 2013). Our data reinforce this literature and suggest that new therapeutic strategies to treat or prevent intestinal motility or bowel inflammatory diseases may be targeted to the nervous system instead of the immune system.

\section{References}

Akimoto M, Baba A, Ikeda-Matsuo Y, Yamada MK, Itamura R, Nishiyama N, Ikegaya Y, Matsuki N (2004) Hepatocyte growth factor as an enhancer of nmda currents and synaptic plasticity in the hippocampus. Neuroscience 128:155-162. CrossRef Medline

Arthur LG, Schwartz MZ, Kuenzler KA, Birbe R (2004) Hepatocyte growth factor treatment ameliorates diarrhea and bowel inflammation in a rat model of inflammatory bowel disease. J Pediatr Surg 39:139-143, discussion 139-143. Medline

Baliu-Piqué M, Jusek G, Holzmann B (2014) Neuroimmunological communication via CGRP promotes the development of a regulatory phenotype in TLR4-stimulated macrophages. Eur J Immunol 44:3708-3716. CrossRef Medline

Bischoff SC, Mailer R, Pabst O, Weier G, Sedlik W, Li Z, Chen JJ, Murphy DL, Gershon MD (2009) Role of serotonin in intestinal inflammation: knockout of serotonin reuptake transporter exacerbates 2,4,6trinitrobenzene sulfonic acid colitis in mice. Am J Physiol Gastrointest Liver Physiol 296:G685-G695. CrossRef Medline

Bjerknes M, Cheng H (2001) Modulation of specific intestinal epithelial progenitors by enteric neurons. Proc Natl Acad Sci U S A 98:1249712502. CrossRef Medline

Boesmans W, Gomes P, Janssens J, Tack J, Vanden Berghe P (2008) Brainderived neurotrophic factor amplifies neurotransmitter responses and promotes synaptic communication in the enteric nervous system. Gut 57:314-322. CrossRef Medline

Bornstein JC, Costa M, Grider JR (2004) Enteric motor and interneuronal circuits controlling motility. Neurogastroenterol Motil 16 [Suppl 1]: 34-38. Medline

Brun P, Giron MC, Qesari M, Porzionato A, Caputi V, Zoppellaro C, Banzato S, Grillo AR, Spagnol L, De Caro R, Pizzuti D, Barbieri V, Rosato A, Sturniolo GC, Martines D, Zaninotto G, Palù G, Castagliuolo I (2013) Toll-like receptor 2 regulates intestinal inflammation by controlling integrity of the enteric nervous system. Gastroenterology 145:1323-1333. CrossRef Medline

Bush TG, Savidge TC, Freeman TC, Cox HJ, Campbell EA, Mucke L, Johnson MH, Sofroniew MV (1998) Fulminant jejuno-ileitis following ablation of enteric glia in adult transgenic mice. Cell 93:189-201. CrossRef Medline

Caton A, Hacker A, Naeem A, Livet J, Maina F, Bladt F, Klein R, Birchmeier C, Guthrie S (2000) The branchial arches and HGF are growth-promoting and chemoattractant for cranial motor axons. Development 127:17511766. Medline

Chalazonitis A, Rothman TP, Chen J, Lamballe F, Barbacid M, Gershon MD (1994) Neurotrophin-3 induces neural crest-derived cells from fetal rat gut to develop in vitro as neurons or glia. J Neurosci 14:6571-6584. Medline

Chalazonitis A, Rothman TP, Chen J, Gershon MD (1998) Age-dependent differences in the effects of GDNF and NT-3 on the development of neurons and glia from neural crest-derived precursors immunoselected from the fetal rat gut: expression of GFRalpha-1 in vitro and in vivo. Dev Biol 204:385-406. CrossRef Medline

Chalazonitis A, Pham TD, Rothman TP, DiStefano PS, Bothwell M, BlairFlynn J, Tessarollo L, Gershon MD (2001) Neurotrophin-3 is required for the survival-differentiation of subsets of developing enteric neurons. J Neurosci 21:5620-5636. Medline

Chandrasekharan B, Nezami BG, Srinivasan S (2013) Emerging neuropep- tide targets in inflammation: NPY and VIP. Am J Physiol Gastrointest Liver Physiol 304:G949-G957. CrossRef Medline

Clerc N, Furness JB (2004) Intrinsic primary afferent neurones of the digestive tract. Neurogastroenterol Motil 16 [Suppl 1]:24-27.

Costantini F (2010) GDNF/Ret signaling and renal branching morphogenesis: from mesenchymal signals to epithelial cell behaviors. Organogenesis 6:252-262. CrossRef Medline

Creedon DJ, Tansey MG, Baloh RH, Osborne PA, Lampe PA, Fahrner TJ, Heuckeroth RO, Milbrandt J, Johnson EMJ (1997) Neurturin shares receptors and signal transduction pathways with glial cell line-derived neurotrophic factor in sympathetic neurons. ProcNatl Acad Sci USA 94: 7018-7023. CrossRef Medline

Danielian PS, Muccino D, Rowitch DH, Michael SK, McMahon AP (1998) Modification of gene activity in mouse embryos in utero by a tamoxifeninducible form of Cre recombinase. Curr Biol 8:1323-1326. CrossRef Medline

Ebens A, Brose K, Leonardo ED, Hanson MG Jr, Bladt F, Birchmeier C, Barres BA, Tessier-Lavigne M (1996) Hepatocyte growth factor/scatter factor is an axonal chemoattractant and a neurotrophic factor for spinal motor neurons. Neuron 17:1157-1172. CrossRef Medline

Engel MA, Becker C, Reeh PW, Neurath MF (2011) Role of sensory neurons in colitis: increasing evidence for a neuroimmune link in the gut. Inflamm Bowel Dis 17:1030-1033. CrossRef Medline

Engel MA, Khalil M, Siklosi N, Mueller-Tribbensee SM, Neuhuber WL, Neurath MF, Becker C, Reeh PW (2012) Opposite effects of substance P and calcitonin gene-related peptide in oxazolone colitis. Dig Liver Dis 44:24-29. CrossRef Medline

Eysselein VE, Reinshagen M, Patel A, Davis W, Nast C, Sternini C (1992) Calcitonin gene-related peptide in inflammatory bowel disease and experimentally induced colitis. Ann N Y Acad Sci 657:319-327. CrossRef Medline

Freem LJ, Escot S, Tannahill D, Druckenbrod NR, Thapar N, Burns AJ (2010) The intrinsic innervation of the lung is derived from neural crest cells as shown by optical projection tomography in Wnt1-Cre;YFP reporter mice. J Anat 217:651-664. CrossRef Medline

Frykman PK, Short SS (2012) Hirschsprung-associated enterocolitis: prevention and therapy. Semin Pediatr Surg 21:328-335. CrossRef Medline

Fu M, Vohra BP, Wind D, Heuckeroth RO (2006) BMP signaling regulates murine enteric nervous system precursor migration, neurite fasciculation, and patterning via altered Ncam1 polysialic acid addition. Dev Biol 299:137-150. CrossRef Medline

Furness JB (2006a) Novel gut afferents: intrinsic afferent neurons and intestinofugal neurons. Auton Neurosci 125:81-85. CrossRef Medline

Furness JB (2006b) The enteric nervous system. Malden, MA: Blackwell.

Furness JB (2012) The enteric nervous system and neurogastroenterology. Nat Rev Gastroenterol Hepatol 9:286-294. CrossRef Medline

Furness JB, Jones C, Nurgali K, Clerc N (2004a) Intrinsic primary afferent neurons and nerve circuits within the intestine. Prog Neurobiol 72:143164. CrossRef Medline

Furness JB, Robbins HL, Xiao J, Stebbing MJ, Nurgali K (2004b) Projections and chemistry of Dogiel type II neurons in the mouse colon. Cell Tissue Res 317:1-12. Medline

Garzotto D, Giacobini P, Crepaldi T, Fasolo A, De Marchis S (2008) Hepatocyte growth factor regulates migration of olfactory interneuron precursors in the rostral migratory stream through Met-Grb2 coupling. J Neurosci 28:5901-5909. CrossRef Medline

Gascon E, Gaillard S, Malapert P, Liu Y, Rodat-Despoix L, Samokhvalov IM, Delmas P, Helmbacher F, Maina F, Moqrich A (2010) Hepatocyte growth factor-Met signaling is required for Runxl extinction and peptidergic differentiation in primary nociceptive neurons. J Neurosci 30: 12414-12423. CrossRef Medline

Gershon MD (2012) Serotonin is a sword and a shield of the bowel: serotonin plays offense and defense. Trans Am Clin Climatol Assoc 123:268280; discussion 280. Medline

Ghia JE, Blennerhassett P, Kumar-Ondiveeran H, Verdu EF, Collins SM (2006) The vagus nerve: a tonic inhibitory influence associated with inflammatory bowel disease in a murine model. Gastroenterology 131: 1122-1130. CrossRef Medline

Ghia JE, Blennerhassett P, El-Sharkawy RT, Collins SM (2007) The protective effect of the vagus nerve in a murine model of chronic relapsing colitis. Am J Physiol Gastrointest Liver Physiol 293:G711-G718. CrossRef Medline 
Giacobini P, Messina A, Wray S, Giampietro C, Crepaldi T, Carmeliet P, Fasolo A (2007) Hepatocyte growth factor acts as a motogen and guidance signal for gonadotropin hormone-releasing hormone-1 neuronal migration. J Neurosci 27:431-445. CrossRef Medline

Gianino S, Grider JR, Cresswell J, Enomoto H, Heuckeroth RO (2003) GDNF availability determines enteric neuron number by controlling precursor proliferation. Development 130:2187-2198. CrossRef Medline

Goldstein AM, Hofstra RM, Burns AJ (2013) Building a brain in the gut: development of the enteric nervous system. Clin Genet 83:307-316. CrossRef Medline

Gong R (2008) Multi-target anti-inflammatory action of hepatocyte growth factor. Curr Opin Investig Drugs 9:1163-1170. Medline

Grider JR, Jin JG (1994) Distinct populations of sensory neurons mediate the peristaltic reflex elicited by muscle stretch and mucosal stimulation. J Neurosci 14:2854-2860. Medline

Grider JR, Acevedo JR, Bushman T (1997a) Stimulation of neurite growth in cultured myenteric neurons by the ciliary neurotrophic factor, CNTF. Gastroenterology 112.

Grider JR, Acevedo JR, Bushman T (1997b) Inhibition of neurite growth by BDNF, a neurotrophic factor expressed and secreted by myenteric neurons in culture. Gastroenterology 112:A739.

Grider JR, Heuckeroth RO, Kuemmerle JF, Murthy KS (2010) Augmentation of the ascending component of the peristaltic reflex and substance $P$ release by glial cell line-derived neurotrophic factor. Neurogastroenterol Motil 22:779-786. CrossRef Medline

Gross ER, Gershon MD, Margolis KG, Gertsberg ZV, Li Z, Cowles RA (2012) Neuronal serotonin regulates growth of the intestinal mucosa in mice. Gastroenterology 143:408-417.e2. CrossRef Medline

Grundy D, Schemann M (2005) Enteric nervous system. Curr Opin Gastroenterol 21:176-182. CrossRef Medline

Guan X, Karpen HE, Stephens J, Bukowski JT, Niu S, Zhang G, Stoll B, Finegold MJ, Holst JJ, Hadsell DL, Nichols BL, Burrin DG (2006) GLP-2 receptor localizes to enteric neurons and endocrine cells expressing vasoactive peptides and mediates increased blood flow. Gastroenterology 130: 150-164. CrossRef Medline

Haase G, Dessaud E, Garces A, de Bovis B, Birling M, Filippi P, Schmalbruch $\mathrm{H}$, Arber S, deLapeyrière O (2002) GDNF acts through PEA3 to regulate cell body positioning and muscle innervation of specific motor neuron pools. Neuron 35:893-905. CrossRef Medline

Hadzijahic N, Renehan WE, Ma CK, Zhang X, Fogel R (1993) Myenteric plexus destruction alters morphology of rat intestine. Gastroenterology 105:1017-1028. Medline

Hanawa T, Suzuki K, Kawauchi Y, Takamura M, Yoneyama H, Han GD, Kawachi H, Shimizu F, Asakura H, Miyazaki J, Maruyama H, Aoyagi Y (2006) Attenuation of mouse acute colitis by naked hepatocyte growth factor gene transfer into the liver. J Gene Med 8:623-635. CrossRef Medline

Hearn CJ, Murphy M, Newgreen D (1998) GDNF and ET-3 differentially modulate the numbers of avian enteric neural crest cells and enteric neurons in vitro. Dev Biol 197:93-105. CrossRef Medline

Heredia DJ, Gershon MD, Koh SD, Corrigan RD, Okamoto T, Smith TK (2013) Important role of mucosal serotonin in colonic propulsion and peristaltic reflexes: in vitro analyses in mice lacking tryptophan hydroxylase 1. J Physiol 591:5939-5957. CrossRef Medline

Heuckeroth RO (2013) Hirschsprung disease. In: Pediatric neurogastroenterology: gastrointestinal motility and functional disorders in children (Faure C, DiLorenzo C, Thapar N, eds), pp 271-283. New York: Springer.

Heuckeroth RO, Lampe PA, Johnson EM, Milbrandt J (1998) Neurturin and GDNF promote proliferation and survival of enteric neuron and glial progenitors in vitro. Dev Biol 200:116-129. CrossRef Medline

Heuckeroth RO, Enomoto H, Grider JR, Golden JP, Hanke JA, Jackman A, Molliver DC, Bardgett ME, Snider WD, Johnson EM Jr, Milbrandt J (1999) Gene targeting reveals a critical role for neurturin in the development and maintenance of enteric, sensory, and parasympathetic neurons. Neuron 22:253-263. CrossRef Medline

Hitch MC, Leinicke JA, Wakeman D, Guo J, Erwin CR, Rowland KJ, Merrick EC, Heuckeroth RO, Warner BW (2012) Ret heterozygous mice have enhanced intestinal adaptation after massive small bowel resection. Am J Physiol Gastrointest Liver Physiol 302:G1143-G1150. CrossRef Medline

Hoffmann P, Hoeck K, Deters S, Werner-Martini I, Schmidt WE (2010) Substance $\mathrm{P}$ and calcitonin gene related peptide induce TGF-alpha ex- pression in epithelial cells via mast cells and fibroblasts. Regul Pept 161: 33-37. CrossRef Medline

Holle GE (1991) Changes in the structure and regeneration mode of the rat small intestinal mucosa following benzalkonium chloride treatment. Gastroenterology 101:1264-1273. Medline

Holle GE, Dietl J, Demir I (2003) Influence of the intramural innervation on the morphogenesis of the enteroendocrine cells and the genetic construct involved (review). Int J Mol Med 11:275-285. Medline

Huh CG, Factor VM, Sánchez A, Uchida K, Conner EA, Thorgeirsson SS (2004) Hepatocyte growth factor/c-met signaling pathway is required for efficient liver regeneration and repair. Proc Natl Acad Sci U S A 101: 4477-4482. CrossRef Medline

Jain S, Golden JP, Wozniak D, Pehek E, Johnson EM Jr, Milbrandt J (2006) RET is dispensable for maintenance of midbrain dopaminergic neurons in adult mice. J Neurosci 26:11230-11238. CrossRef Medline

Jing S, Wen D, Yu Y, Holst PL, Luo Y, Fang M, Tamir R, Antonio L, Hu Z, Cupples R, Louis JC, Hu S, Altrock BW, Fox GM (1996) GDNF-induced activation of the ret protein tyrosine kinase is mediated by GDNFR-alpha, a novel receptor for GDNF. Cell 85:1113-1124. CrossRef Medline

Kanbe T, Murai R, Mukoyama T, Murawaki Y, Hashiguchi K, Yoshida Y, Tsuchiya H, Kurimasa A, Harada K, Yashima K, Nishimuki E, Shabana N, Kishimoto Y, Kojyo H, Miura K, Murawaki Y, Kawasaki H, Shiota G (2006) Naked gene therapy of hepatocyte growth factor for dextran sulfate sodium-induced colitis in mice. Biochem Biophys Res Commun 345: 1517-1525. CrossRef Medline

Kunze WA, Clerc N, Bertrand PP, Furness JB (1999) Contractile activity in intestinal muscle evokes action potential discharge in guinea-pig myenteric neurons. J Physiol 517:547-561. CrossRef Medline

Kuure S, Chi X, Lu B, Costantini F (2010) The transcription factors Etv4 and Etv5 mediate formation of the ureteric bud tip domain during kidney development. Development 137:1975-1979. CrossRef Medline

Lake JI, Heuckeroth RO (2013) Enteric nervous system development: migration, differentiation, and disease. Am J Physiol Gastrointest Liver Physiol 305:G1-G24. CrossRef Medline

Lamballe F, Genestine M, Caruso N, Arce V, Richelme S, Helmbacher F, Maina F (2011) Pool-specific regulation of motor neuron survival by neurotrophic support. J Neurosci 31:11144-11158. CrossRef Medline

Landau AM, Yashpal K, Cahill CM, St Louis M, Ribeiro-da-Silva A, Henry JL (2007) Sensory neuron and substance P involvement in symptoms of a zymosan-induced rat model of acute bowel inflammation. Neuroscience 145:699-707. CrossRef Medline

Lee J, Yamamoto T, Kuramoto H, Kadowaki M (2012) TRPV1 expressing extrinsic primary sensory neurons play a protective role in mouse oxazolone-induced colitis. Auton Neurosci 166:72-76. CrossRef Medline

Li Z, Chalazonitis A, Huang YY, Mann JJ, Margolis KG, Yang QM, Kim DO, Côté F, Mallet J, Gershon MD (2011) Essential roles of enteric neuronal serotonin in gastrointestinal motility and the development/survival of enteric dopaminergic neurons. J Neurosci 31:8998-9009. CrossRef Medline

Lim CS, Walikonis RS (2008) Hepatocyte growth factor and c-Met promote dendritic maturation during hippocampal neuron differentiation via the Akt pathway. Cell Signal 20:825-835. CrossRef Medline

Livet J, Sigrist M, Stroebel S, De Paola V, Price SR, Henderson CE, Jessell TM, Arber S (2002) ETS gene Pea3 controls the central position and terminal arborization of specific motor neuron pools. Neuron 35:877-892. CrossRef Medline

Lu BC, Cebrian C, Chi X, Kuure S, Kuo R, Bates CM, Arber S, Hassell J, MacNeil L, Hoshi M, Jain S, Asai N, Takahashi M, Schmidt-Ott KM, Barasch J, D'Agati V, Costantini F (2009) Etv4 and Etv5 are required downstream of GDNF and Ret for kidney branching morphogenesis. Nat Genet 41:1295-1302. CrossRef Medline

Lundgren O, Jodal M, Jansson M, Ryberg AT, Svensson L (2011) Intestinal epithelial stem/progenitor cells are controlled by mucosal afferent nerves. PLoS One 6:e16295. CrossRef Medline

Maina F, Hilton MC, Ponzetto C, Davies AM, Klein R (1997) Met receptor signaling is required for sensory nerve development and HGF promotes axonal growth and survival of sensory neurons. Genes Dev 11:3341-3350. CrossRef Medline

Maina F, Hilton MC, Andres R, Wyatt S, Klein R, Davies AM (1998) Multiple roles for hepatocyte growth factor in sympathetic neuron development. Neuron 20:835-846. CrossRef Medline 
Margolis KG, Gershon MD (2009) Neuropeptides and inflammatory bowel disease. Curr Opin Gastroenterol 25:503-511. CrossRef Medline

Margolis KG, Stevanovic K, Karamooz N, Li ZS, Ahuja A, D’Autréaux F, Saurman V, Chalazonitis A, Gershon MD (2011) Enteric neuronal density contributes to the severity of intestinal inflammation. Gastroenterology 141:588-598, 598.e1-2. CrossRef Medline

Matsubayashi Y, Iwai L, Kawasaki H (2008) Fluorescent double-labeling with carbocyanine neuronal tracing and immunohistochemistry using a cholesterol-specific detergent digitonin. J Neurosci Methods 174:71-81. CrossRef Medline

Mazelin L, Theodorou V, Fioramonti J, Bueno L (1999) Vagally dependent protective action of calcitonin gene-related peptide on colitis. Peptides 20:1367-1374. CrossRef Medline

Miller MS, Galligan JJ, Burks TF (1981) Accurate measurement of intestinal transit in the rat. J Pharmacol Methods 6:211-217. CrossRef Medline

Moore MW, Klein RD, Fariñas I, Sauer H, Armanini M, Phillips H, Reichardt LF, Ryan AM, Carver-Moore K, Rosenthal A (1996) Renal and neuronal abnormalities in mice lacking GDNF. Nature 382:76-79. CrossRef Medline

Mukoyama T, Kanbe T, Murai R, Murawaki Y, Shimomura T, Hashiguchi K, Saeki T, Ichiba M, Yoshida Y, Tanabe N, Kurimasa A, Harada K, Yashima K, Hisatome I, Ito H, Shiota G (2005) Therapeutic effect of adenoviralmediated hepatocyte growth factor gene administration on TNBSinduced colitis in mice. Biochem Biophys Res Commun 329:1217-1224. CrossRef Medline

Mulholland MW, Romanchuk G, Lally K, Simeone DM (1994) Nerve growth factor promotes neurite outgrowth in guinea pig myenteric plexus ganglia. Am J Physiol 267:G716-G722. Medline

Nezami BG, Srinivasan S (2010) Enteric nervous system in the small intestine: pathophysiology and clinical implications. Curr Gastroenterol Rep 12:358-365. CrossRef Medline

Numata M, Ido A, Moriuchi A, Kim I, Tahara Y, Yamamoto S, Hasuike S, Nagata K, Miyata Y, Uto H, Tsubouchi H (2005) Hepatocyte growth factor facilitates the repair of large colonic ulcers in 2,4,6-trinitrobenzene sulfonic acid-induced colitis in rats. Inflamm Bowel Dis 11:551-558. CrossRef Medline

Obermayr F, Hotta R, Enomoto H, Young HM (2013) Development and developmental disorders of the enteric nervous system. Nat Rev Gastroenterol Hepatol 10:43-57. CrossRef Medline

Oh K, Iimuro Y, Takeuchi M, Kaneda Y, Iwasaki T, Terada N, Matsumoto T, Nakanishi K, Fujimoto J (2005) Ameliorating effect of hepatocyte growth factor on inflammatory bowel disease in a murine model. Am J Physiol Gastrointest Liver Physiol 288:G729-G735. CrossRef Medline

Ohda Y, Hori K, Tomita T, Hida N, Kosaka T, Fukuda Y, Miwa H, Matsumoto T (2005) Effects of hepatocyte growth factor on rat inflammatory bowel disease models. Dig Dis Sci 50:914-921. CrossRef Medline

Pan H, Gershon MD (2000) Activation of intrinsic afferent pathways in submucosal ganglia of the guinea pig small intestine. J Neurosci 20:32953309. Medline

Patel BA (2014) Mucosal adenosine triphosphate mediates serotonin release from ileal but not colonic guinea pig enterochromaffin cells. Neurogastroenterol Motil 26:237-246. CrossRef Medline

Pawlik WW, Obuchowicz R, Biernat J, Sendur R, Jaworek J (2000) Role of calcitonin gene related peptide in the modulation of intestinal circulatory, metabolic, and myoelectric activity during ischemia/reperfusion. J Physiol Pharmacol 51:933-942. Medline

Prat M, Narsimhan RP, Crepaldi T, Nicotra MR, Natali PG, Comoglio PM (1991) The receptor encoded by the human c-MET oncogene is expressed in hepatocytes, epithelial cells and solid tumors. Int J Cancer 49:323-328. CrossRef Medline

Pull SL, Doherty JM, Mills JC, Gordon JI, Stappenbeck TS (2005) Activated macrophages are an adaptive element of the colonic epithelial progenitor niche necessary for regenerative responses to injury. Proc Natl Acad Sci U S A 102:99-104. CrossRef Medline

Qu ZD, Thacker M, Castelucci P, Bagyánszki M, Epstein ML, Furness JB (2008) Immunohistochemical analysis of neuron types in the mouse small intestine. Cell Tissue Res 334:147-161. CrossRef Medline

Ramachandran R, Hyun E, Zhao L, Lapointe TK, Chapman K, Hirota CL, Ghosh S, McKemy DD, Vergnolle N, Beck PL, Altier C, Hollenberg MD (2013) TRPM8 activation attenuates inflammatory responses in mouse models of colitis. Proc Natl Acad Sci U S A 110:7476-7481. CrossRef Medline
Raybould HE, Cooke HJ, Christofi FL (2004) Sensory mechanisms: transmitters, modulators and reflexes. Neurogastroenterol Motil 16 [Suppl 1]: 60-63. Medline

Sánchez MP, Silos-Santiago I, Frisén J, He B, Lira SA, Barbacid M (1996) Renal agenesis and the absence of enteric neurons in mice lacking GDNF. Nature 382:70-73. CrossRef Medline

Sasselli V, Pachnis V, Burns AJ (2012) The enteric nervous system. Dev Biol 366:64-73. CrossRef Medline

Sato Y, Heuckeroth RO (2008) Retinoic acid regulates murine enteric nervous system precursor proliferation, enhances neuronal precursor differentiation, and reduces neurite growth in vitro. Dev Biol 320:185-198. CrossRef Medline

Savidge TC, Newman P, Pothoulakis C, Ruhl A, Neunlist M, Bourreille A, Hurst R, Sofroniew MV (2007) Enteric glia regulate intestinal barrier function and inflammation via release of S-nitrosoglutathione. Gastroenterology 132:1344-1358. CrossRef Medline

Schäfer KH, Hagl CI, Rauch U (2003) Differentiation of neurospheres from the enteric nervous system. Pediatr Surg Int 19:340-344. CrossRef Medline

Schuchardt A, D'Agati V, Larsson-Blomberg L, Costantini F, Pachnis V (1994) Defects in the kidney and enteric nervous system of mice lacking the tyrosine kinase receptor Ret. Nature 367:380-383. CrossRef Medline Setoyama H, Ido A, Numata M, Moriuchi A, Yamaji N, Tamai T, Funakawa K, Fujita H, Sakiyama T, Uto H, Oketani M, Tsubouchi H (2011) Repeated enemas with hepatocyte growth factor selectively stimulate epithelial cell proliferation of injured mucosa in rats with experimental colitis. Life Sci 89:269-275. CrossRef Medline

Sharkey KA, Savidge TC (2014) Role of enteric neurotransmission in host defense and protection of the gastrointestinal tract. Auton Neurosci 181: 94-106. CrossRef Medline

Srinivasan S, Anitha M, Mwangi S, Heuckeroth RO (2005) Enteric neuroblasts require the phosphatidylinositol 3-kinase/Akt/Forkhead pathway for GDNF-stimulated survival. Mol Cell Neurosci 29:107-119. CrossRef Medline

Sun L, Miyoshi H, Origanti S, Nice TJ, Barger AC, Manieri NA, Fogel LA, French AR, Piwnica-Worms D, Piwnica-Worms H, Virgin HW, Lenschow DJ, Stappenbeck TS (2015) Type I interferons link viral infection to enhanced epithelial turnover and repair. Cell Host Microbe 17:85-97. CrossRef Medline

Tahara Y, Ido A, Yamamoto S, Miyata Y, Uto H, Hori T, Hayashi K, Tsubouchi H (2003) Hepatocyte growth factor facilitates colonic mucosal repair in experimental ulcerative colitis in rats. J Pharmacol Exp Ther 307: 146-151. CrossRef Medline

Takami Y, Mantyh CR, Pappas TN, Takahashi T, Koda K, Miyazaki M (2009) Extrinsic surgical denervation ameliorates TNBS-induced colitis in rats. Hepatogastroenterology 56:682-686. Medline

Thompson BJ, Washington MK, Kurre U, Singh M, Rula EY, Emeson RB (2008) Protective roles of alpha-calcitonin and beta-calcitonin generelated peptide in spontaneous and experimentally induced colitis. Dig Dis Sci 53:229-241. CrossRef Medline

Thompson J, Dolcet X, Hilton M, Tolcos M, Davies AM (2004) HGF promotes survival and growth of maturing sympathetic neurons by PI-3 kinase- and MAP kinase-dependent mechanisms. Mol Cell Neurosci 27: 441-452. CrossRef Medline

Tönges L, Ostendorf T, Lamballe F, Genestine M, Dono R, Koch JC, Bähr M, Maina F, Lingor P (2011) Hepatocyte growth factor protects retinal ganglion cells by increasing neuronal survival and axonal regeneration in vitro and in vivo. J Neurochem 117:892-903. CrossRef Medline

Treanor JJ, Goodman L, de Sauvage F, Stone DM, Poulsen KT, Beck CD, Gray C, Armanini MP, Pollock RA, Hefti F, Phillips HS, Goddard A, Moore MW, Buj-Bello A, Davies AM, Asai N, Takahashi M, Vandlen R, Henderson CE, Rosenthal A (1996) Characterization of a multicomponent receptor for GDNF. Nature 382:80-83. CrossRef Medline

Trusolino L, Bertotti A, Comoglio PM (2010) MET signalling: principles and functions in development, organ regeneration and cancer. Nat Rev Mol Cell Biol 11:834-848. CrossRef Medline

Tutton PJ (1975) The influence of cholinoceptor activity on the mitotic rate in the crypts of Lieberkuhn in rat jejunum. Clin Exp Pharmacol Physiol 2:269-276. CrossRef Medline

Uesaka T, Jain S, Yonemura S, Uchiyama Y, Milbrandt J, Enomoto H (2007) Conditional ablation of GFRalphal in postmigratory enteric neurons triggers unconventional neuronal death in the colon and causes a Hirsch- 
sprung's disease phenotype. Development 134:2171-2181. CrossRef Medline

Uesaka T, Nagashimada M, Yonemura S, Enomoto H (2008) Diminished Ret expression compromises neuronal survival in the colon and causes intestinal aganglionosis in mice. J Clin Invest 118:1890-1898. CrossRef Medline

Uesaka T, Nagashimada M, Enomoto H (2013) GDNF signaling levels control migration and neuronal differentiation of enteric ganglion precursors. J Neurosci 33:16372-16382. CrossRef Medline

Van Der Zanden EP, Boeckxstaens GE, de Jonge WJ (2009) The vagus nerve as a modulator of intestinal inflammation. Neurogastroenterol Motil 21: 6-17. CrossRef Medline

Vohra BP, Tsuji K, Nagashimada M, Uesaka T, Wind D, Fu M, Armon J, Enomoto H, Heuckeroth RO (2006) Differential gene expression and functional analysis implicate novel mechanisms in enteric nervous system precursor migration and neuritogenesis. Dev Biol 298:259-271. CrossRef Medline

Wang H, Hughes I, Planer W, Parsadanian A, Grider JR, Vohra BP, KellerPeck C, Heuckeroth RO (2010) The timing and location of glial cell line-derived neurotrophic factor expression determine enteric nervous system structure and function. J Neurosci 30:1523-1538. CrossRef Medline

Wang J, Qiu X, Kulkarni A, Hauer-Jensen M (2006) Calcitonin gene-related peptide and substance $\mathrm{P}$ regulate the intestinal radiation response. Clin Cancer Res 12:4112-4118. CrossRef Medline

Wood JD (2008) Enteric nervous system: reflexes, pattern generators and motility. Curr Opin Gastroenterol 24:149-158. CrossRef Medline

Wu HH, Levitt P (2013) Prenatal expression of MET receptor tyrosine kinase in the fetal mouse dorsal raphe nuclei and the visceral motor/sensory brainstem. Dev Neurosci 35:1-16. CrossRef Medline

Zhou Y, Yang J, Watkins DJ, Boomer LA, Matthews MA, Su Y, Besner GE (2013) Enteric nervous system abnormalities are present in human necrotizing enterocolitis: potential neurotransplantation therapy. Stem Cell Res Ther 4:157. CrossRef Medline

Zucoloto S, Diaz JA, Oliveira JS, Muccilo G, Sales Neto VN, Kajiwara JK (1988) Effect of chemical ablation of myenteric neurones on intestinal cell proliferation. Cell Tissue Kinet 21:213-219. Medline 